\title{
The Impact of Doing Business Regulations on \\ INVESTMENTS IN ICT
}

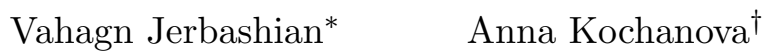

\begin{abstract}
Using industry-level data from 14 OECD countries and doing business indicators of the World Bank, we analyze how country-level regulations of business activities affect investments in information and communication technologies (ICT). We find that investments in ICT decrease with the costs of starting and operating a business and registering property. Investments increase with the strength of legal rights. We also find that investments in software increase with the ability of shareholders to sue managers for misconduct, and investments in communication technologies decline with the extent of director liability for self-dealing.
\end{abstract}

Keywords Investments in ICT; Regulations of Doing Business

JEL classifications O38; O25; O43; L50

\footnotetext{
*University of Barcelona and CERGE-EI.

Address (corresponding author): University of Barcelona, Avenue Diagonal 696, 08034 Barcelona, Spain. Phone: +34934039081. E-mail: vahagn.jerbashian@ub.edu

${ }^{\dagger}$ Max Planck Institute for Research on Collective Goods.

CERGE-EI is a joint workplace of the Center for Economic Research and Graduate Education, Charles University in Prague, and the Economics Institute of Academy of Sciences of the Czech Republic.
} 


\section{Introduction}

There is a growing debate whether and how country-level regulations of doing business matter for aggregate performance (Klapper et al, 2006; Djankov et al, 2006; Barseghyan, 2008; Branstetter et al, 2014). In turn, empirical evidence suggests that one of the significant drivers behind recent improvements in aggregate performance are investments in information and communication technologies (ICT) (Jorgenson et al, 2005; Ketteni et al, 2007, 2011; Venturini, 2009).

In this paper, we investigate how country-level regulations of business activities affect industrylevel investments in ICT. In order to alleviate endogeneity concerns, we use a difference-in-differences framework in the spirit of Rajan and Zingales (1998). More specifically, we ask whether ex ante differences in country-level regulations affect investments in ICT differently in industries that depend more on these technologies compared to the industries that depend less. To establish our results, we use industry- and country-level data from 14 OECD countries and the World Bank's doing business indicators. In particular, we focus on indicators related to starting business, registering property, getting credit, protecting investors, and paying taxes.

Our results suggest that investments in ICT decline with the number of procedures, time, and monetary costs required for starting a business, and procedures and time required for registering property. Investments in ICT also decline with the number of tax payments and time required for compiling tax payments. In turn, investments increase with the strength of legal rights. We fail to establish any systematic evidence that the monetary costs required for registering property affect investments in ICT. However, we find that they significantly reduce investments in information technologies (IT) and software. Further, we fail to establish any systematic evidence that the ability of shareholders to sue managers for misconduct and the extent of director liability for selfdealing affect investments in ICT. We find, however, that increasing the ability of shareholders to sue managers increases investments in software and increasing the extent of director liability reduces investments in communication technologies (CT).

Many studies show that the regulations of business activities matter for economic growth (e.g., Djankov et al, 2006; Haidar, 2009; Barseghyan, 2008; Haidar, 2012). In particular, they find that countries with less burdensome regulations grow faster. Given that investments in ICT contribute significantly to economic growth (e.g., Jorgenson et al, 2005; Venturini, 2009), our findings suggest a possible driver behind the results of such macro-level empirical studies.

Our findings can also be interesting for policymakers. They suggest possible policy instruments which can increase investments in ICT and, therefore, aid and compliment policy agendas such as the Digital Agenda in Europe. Moreover, the indicators of doing business regulations which we employ are widely used in academia and by policymakers (Djankov, 2009). In both developing and developed countries, policymakers often evaluate country-level regulatory environment and gains from further (de-)regulations using these indicators. Our results provide explicit support for that.

Primarily, this paper is related to studies which identify the impact of regulations on investments in ICT (e.g., Gruber and Verboven, 2001; Gust and Marquez, 2004; Heli and Kretschmer, 2005; Andonova and Diaz-Serrano, 2009; Nardotto et al, 2012; Grajek and Röller, 2012). It is also related to studies which analyze the impact of policies on investments and, particularly, on investments in intangible assets (e.g., Carlin and Mayer, 2003; Claessens and Laeven, 2003). Typically, these studies focus on particular industries and policies and find that less red-tape and deregulation encourage investments. This paper contributes to these studies by assessing the impact countrylevel regulations of doing business on industry-level investments in ICT. There is also a growing 
number of studies which investigate the impact of institutions and various regulations on economic performance (e.g., Acemoglu et al, 2001; Bena et al, 2011; Amin and Haidar, 2012). This paper contributes to these studies to the extent that one of the pronounced drivers of recent surge in economic performance are the investments in ICT.

The reminder of the paper is organized as follows. The next section offers a simple model to motivate the empirical test. The third section offers the empirical specification, and describes the data and its sources. The fourth section summarizes the results, and the last section concludes. The tables of basic statistics and regression results are presented at the end of the paper.

\section{Theoretical Model}

A regulation, which is common to all industries, would penalize (or subsidize) investments in information and communication technologies more in industries which depend more on these technologies. ${ }^{1}$ To show explicitly how such an inference can hold and set the stage for the empirical analysis, we develop a stylized deterministic model which follows the model of Alesina et al (2005).

We consider an industry where $N$ infinitely lived firms produce horizontally differentiated goods $x$, indexed by $j$. For simplicity, let the production function of a good $j(\forall j=1, \ldots, N)$ be

$$
x_{j}=A k_{j}^{\alpha} m_{j}^{1-\alpha},
$$

where $A>0$ is an exogenous productivity level, $k$ is the amount of ICT capital input, $m$ summarizes all other inputs, and $\alpha \in(0,1)$ is output elasticity of ICT capital. In this respect, $\alpha$ measures the dependence on that capital since higher $\alpha$ means higher output elasticity of ICT capital.

The firms can invest and accumulate capital with a technology

$$
\dot{k}=\iota-\delta k,
$$

where $\iota$ is the amount of investment, and the initial value of $k$ is given and is the same for all firms. We further assume that firms incur adjustment costs for installing the newly created capital. Adjustment costs are in terms of the capital and have the standard quadratic form $\frac{b}{2}\left(\frac{\iota}{k}\right)^{2} k$, where $b>0$ is adjustment cost parameter.

To capture the effect of business regulations on firms' profits in a reduced form, we assume that these regulations affect the revenues and the costs of the firms so that the profits of firm $j$ net of investment costs are

$$
\pi_{j}=\left(1-\tau_{x}\right) p_{x_{j}} x_{j}-p_{m} m_{j}-\left(1+\tau_{\iota}\right) p_{\iota} \iota_{j}-\left(1+\tau_{b}\right) p_{\iota} \frac{b}{2}\left(\frac{\iota_{j}}{k_{j}}\right)^{2} k_{j}
$$

where $p_{x_{j}}, p_{m}$, and $p_{\iota}$ are the prices of $x_{j}, m, \iota$ and $k$. In turn, $\tau_{x}, \tau_{\iota}$, and $\tau_{b}$ are the effects of regulations. For example, $\tau_{x}>0$ can represent business taxes, and $\tau_{\iota}<0$ and $\tau_{b}<0$ can represent regulations which subsidize investments or increase their efficiency (returns on investments).

We denote the effective interest rate by $\left(1+\tau_{r}\right) r$, where $r$ is the interest rate and $\tau_{r}$ is the regulation affecting it. This regulation can represent policies which facilitate lending and reduce borrowing costs.

${ }^{1}$ This statement is essentially an analogue of the Rybczynski theorem. 
Suppose that firms in this industry are price setters so that they could coup their investments in ICT. Moreover, $A$ grows at a constant rate $g_{A}$. The problem of the firm $j$ then is

$$
\begin{aligned}
& V_{j}=\max _{p_{x_{j}}, l_{j}, \iota_{j}}\left\{\int_{0}^{+\infty} \pi_{j}(t) e^{-\left[\left(1+\tau_{r}\right) r-g_{A}\right] t} d t\right\} \\
& \text { s.t. } \\
& (1),(2),(3),
\end{aligned}
$$

where the initial value of $A$ is normalized to 1 .

Using $q$ to denote the shadow value of investments and focusing on symmetric equilibrium, the necessary conditions for optimality are given by

$$
\begin{aligned}
& p_{m}=(1-\alpha)\left(1-\tau_{x}\right)\left(1-\frac{1}{e}\right) \frac{x}{m} \\
& q=p_{\iota}\left[\left(1+\tau_{\iota}\right)+\left(1+\tau_{b}\right) b \frac{\iota}{k}\right] \\
& \dot{q}=q\left(1+\tau_{r}\right) r-\left[\alpha\left(1-\tau_{x}\right)\left(1-\frac{1}{e}\right) \frac{x}{k}+\left(1+\tau_{b}\right) p_{\iota} \frac{b}{2}\left(\frac{\iota}{k}\right)^{2}-q \delta\right],
\end{aligned}
$$

where $e$ is the perceived elasticity of substitution, $\frac{1}{e}$ is the Lerner index, and the price of goods $x$ is normalized to 1 . We assume that the demand for goods $x$ is given by a standard CES function with an elasticity of substitution $\varepsilon$. In such a case, it can be shown that $e=e(\varepsilon, N)$, and $e(\varepsilon, N)$ increases with $\varepsilon$ and the number of firms $N$.

It can be shown that this system is saddle-path stable. In the steady-state we obtain

$$
\frac{p_{\iota} k}{x}=\frac{\alpha\left(1-\tau_{x}\right)\left(1-\frac{1}{e}\right)}{\Gamma_{1}}
$$

and

$$
\frac{p_{\iota} \iota}{x}=\left(\delta+g_{A}\right) \frac{p_{\iota} k}{x}
$$

where $\Gamma_{1}$ is given by

$$
\Gamma_{1}=\left(1+\tau_{\iota}\right)\left[\left(1+\tau_{r}\right) r+\delta\right]+\left(1+\tau_{b}\right) b\left(\delta+g_{A}\right)\left[\left(1+\tau_{r}\right) r+\frac{1}{2}\left(\delta-g_{A}\right)\right]
$$

To show the effect of the level of dependence $\alpha$, we consider how the effects of changes in $\tau_{x}$, $\tau_{\iota}, \tau_{b}$, and $\tau_{r}$ on investments relative to output (value added) depend on $\alpha$. It is straightforward to show that the partial derivatives of $\frac{p_{\iota} \iota}{x}$ with respect to $\tau_{x}, \tau_{\iota}, \tau_{b}$, and $\tau_{r}$ are negative. In turn, the following holds for any of these regulations

$$
\frac{\partial}{\partial \alpha}\left|\frac{\partial}{\partial \tau_{h}} \frac{p_{\iota} \iota}{x}\right|=\frac{1}{\alpha}\left|\frac{\partial}{\partial \tau_{h}} \frac{p_{\iota} \iota}{x}\right|
$$

where subscript $h=x, \iota, b, r$. This implies that investments in industries which have higher dependence $(\alpha)$ react more to changes in regulations than in industries which have lower dependence.

Regulations of entry costs could also affect the number of firms. If higher costs of entry reduce the number of firms, then these costs would reduce $e$. In this case, the effect of such policies can be summarized in terms of $\frac{\partial}{\partial(1 / e)} \frac{p_{\iota \iota}}{x}$, which is negative according to (7) and (8). From (7) and (8) it also follows that

$$
\frac{\partial}{\partial \alpha}\left|\frac{\partial}{\partial(1 / e)} \frac{p_{\iota} \iota}{x}\right|=\frac{1}{\alpha}\left|\frac{\partial}{\partial(1 / e)} \frac{p_{\iota} \iota}{x}\right|
$$


which implies that the level of dependence can also matter for policies which affect costs of entry.

For a more rigorous analysis, which shows how entry costs can affect investment decisions for different values of $\alpha$, we endogenize the perceived elasticity of substitution/number of firms. We suppose that all firms enter in the first period and entrants break even on a zero net-value condition, $V=T$, where $T$ represents entry costs. We assume that $T$ is proportional to $k$, so that $T=\bar{\tau} p_{\iota} k$.

From the standard Hamilton-Jacobi-Bellman equation, $\dot{V}=\left[\left(1+\tau_{r}\right) r-g_{A}\right] V-\pi$, it follows that in the steady-state capital gains are zero, $\dot{V}=0$. Therefore, the zero net-value condition is equivalent to

$$
\left(1-\tau_{x}\right) x-p_{m} m-\left(1+\tau_{\iota}\right) p_{\iota} \iota-\left(1+\tau_{b}\right) p_{\iota} \frac{b}{2}\left(\frac{\iota}{k}\right)^{2} k=\left[\left(1+\tau_{r}\right) r-g_{A}\right] \bar{\tau} p_{\iota} k .
$$

From this expression and (4), (8), it follows that

$$
\left[1-(1-\alpha)\left(1-\frac{1}{e}\right)\right]\left(1-\tau_{x}\right) \frac{x}{p_{\iota} k}=\Gamma_{2}+\left[\left(1+\tau_{r}\right) r-g_{A}\right] \bar{\tau},
$$

where we use $\Gamma_{2}$ to denote

$$
\Gamma_{2}=\left(1+\tau_{\iota}\right)\left(\delta+g_{A}\right)+\left(1+\tau_{b}\right) \frac{b}{2}\left(\delta+g_{A}\right)^{2} .
$$

Further, expressing $\left(1-\frac{1}{e}\right)$ in terms of $\frac{p_{\iota} k}{x}$ from (7) and using the expression above gives

$$
\frac{p_{\iota} \iota}{x}=\frac{\left(\delta+g_{A}\right)\left(1-\tau_{x}\right)}{\left[\left(1+\tau_{r}\right) r-g_{A}\right] \bar{\tau}+\frac{1-\alpha}{\alpha} \Gamma_{1}+\Gamma_{2}} .
$$

It can be shown that increasing entry cost $\bar{\tau}$ reduces investments. In turn, the effect of higher dependence is given by

$$
\frac{\partial}{\partial \alpha}\left|\frac{\partial}{\partial \bar{\tau}} \frac{p_{\iota} \iota}{x}\right|=2 \frac{1}{\alpha^{2}} \Gamma_{1} \frac{1}{\left[\left(1+\tau_{r}\right) r-g_{A}\right] \bar{\tau}+\frac{1-\alpha}{\alpha} \Gamma_{1}+\Gamma_{2}}\left|\frac{\partial}{\partial \bar{\tau}} \frac{p_{\iota} \iota}{x}\right|,
$$

which implies that investments react more to the entry cost for higher values of dependence on ICT.

In case entry cost is proportional to the level of output/value added, we would have that

$$
\frac{p_{\iota} \iota}{x}=\frac{\left(\delta+g_{A}\right)\left\{1-\tau_{x}-\left[\left(1+\tau_{r}\right) r-g_{A}\right] \bar{\tau}\right\}}{\frac{1-\alpha}{\alpha} \Gamma_{1}+\Gamma_{2}}{ }^{2}
$$

In this case also it can be shown that higher entry cost reduces investments. Moreover, it can be shown that

$$
\frac{\partial}{\partial \alpha}\left|\frac{\partial}{\partial \bar{\tau}} \frac{p_{\iota} \iota}{x}\right|=\frac{1}{\frac{1-\alpha}{\alpha} \Gamma_{1}+\Gamma_{2}} \frac{1}{\alpha^{2}} \Gamma_{1}\left|\frac{\partial}{\partial \bar{\tau}} \frac{p_{\iota} \iota}{x}\right|
$$

which implies, again, that investments react more to the regulation of entry $\bar{\tau}$ for higher values of dependence on ICT. ${ }^{3}$

In our empirical specification we look exactly for such a disparity across industries for regulations of business activities. Admittedly, however, our reduced form analysis of the likely effects of regulations might not fully encompass the true effects, which might be economy wide and not different across industries. In such a case, our empirical exercise, which we present in the next section, can be also viewed as a test of whether industry-level differences exist.

${ }^{2}$ Clearly, we need to assume that $1-\tau_{x}-\left[\left(1+\tau_{r}\right) r-g_{A}\right] \bar{\tau}>0$ in order to have positive investments.

${ }^{3}$ In case when entry cost is proportional to $m$ similar inference holds for certain parameter values. 


\section{Empirical Methodology and Data}

Our empirical specification tests whether ex ante differences in country-level regulations of business activities, ex post, affect differently ICT investment in industries which depend more on ICT compared to industries which depend less. Such a test has several advantages. It permits country and industry fixed effects, which can be important for capturing, for example, demand and market characteristics, as well as fixed costs of entry into industries. It does not depend on a particular country-level model of investments in ICT capital. Therefore, we can avoid using country-level variables. Moreover, in this respect, it does not depend on country-level drivers behind the implementation of regulations, which alleviates the concerns of endogeneity of the regulations.

The dependent variable in this empirical exercise is the level of investment in ICT capital relative to value added in industry $i$ and country $c$ in our sample. After controlling for industry and country fixed effects, we should find that the coefficient on the interaction between initial level of regulation implementation and industries' dependence on ICT capital is different from zero for regulations which affect investment decisions.

Our empirical specification is then

$$
\begin{aligned}
\text { Investment }_{i, c}= & \beta_{1} \text { (Industry } i \text { 's Dependence } \times \text { Regulation in Country } c \text { ) } \\
& +\beta_{2, i}+\beta_{3, c}+\gamma X_{i, c}+\eta_{i, c},
\end{aligned}
$$

where our focus is on the coefficient of the interaction term $\beta_{1}$. The coefficients $\beta_{2}$ and $\beta_{3}$ are the industry and country fixed effects, and $\eta_{i, c}$ is the error term. In line with the theoretical model, $X_{i, c}$ includes the interest rate (industry rate of return on capital), and a measure of expected growth of TFP. We also include in $X_{i, c}$ the initial level of ICT capital relative to value added, which can capture potential scale effects and path dependence. If a regulation has a positive (negative) effect on investments in ICT then we should find that the estimate of $\beta_{1}$ is positive (negative).

Our empirical specification does not include time dimension. Many studies of investments use time dimension and often base their inference on within-industry variation (Alesina et al, 2005). Given our research question, however, in terms of the methodology we follow another branch in the literature, which uses within-country and between-industry variation to assess investments and growth (Rajan and Zingales, 1998; Carlin and Mayer, 2003). In this sense our study can be thought to be complementary. Moreover, it helps us to focus on within-country and betweenindustry variation because of two reasons. First, we have very limited number of time observations. Second, our country-level business regulation variables have large variation across countries and industry-level dependence variables have large variation across industries. However, these variables tend to vary little over time. We describe our measures and data in detail in the next section.

\subsection{Data and Measures}

We obtain the data for country-level regulations of business activities from the World Bank's Doing Business database. In turn, our source of industry-level data is the EU KLEMS database (March 2011 update of 2009 release). It provides us with data for 30 ISIC industries (ISIC rev. 3), which have aggregation level at 1 - and 2-digits. ${ }^{4}$

\footnotetext{
${ }^{4}$ To our knowledge, this is the only database which contains sufficiently detailed industry-level data.
} 
We exclude the industries that are expected to have a large state involvement (public administration and defence, and compulsory social security; education), since investment decisions in these industries are likely to be not well explained in the frames of our theoretical model. With similar reasoning, we exclude the telecommunications industry, which uses and produces ICT goods. This limits our sample to 27 industries. Moreover, the use of the EU KLEMS database limits our sample to 14 OECD countries.

Admittedly, the use of data from a rather homogenous set of countries involves trade-offs. It can eliminate the influence of various unobservable factors on our results, for example. However, at the same time it can weaken the results from cross-country comparisons.

In this study, we focus on the period 2005-2007. We do so because most of the regulation indicators in the World Bank's Doing Business database are available from 2005 and EU KLEMS data end in 2007. Moreover, 2007 seems to be a convenient cut-off point since it allows us to avoid incorporating data from the recent financial crisis. ${ }^{5}$

\subsubsection{Dependence on ICT}

In a country, a naive measure of an industry's dependence on information and communication technologies (hereafter, ICT dependence) would be its share of compensation of ICT capital out of nominal value added. The problems with this measure can be seen from our model assuming that firms hire ICT capital as they do other inputs. This measure reflects both the supply and the demand of ICT, and distortions thereof, when we need only the demand in order to identify technological differences. To alleviate this problem, we identify ICT dependence from US data, where most likely distortions are the lowest and supply might be treated as perfectly elastic. This identification strategy is widely used in the literature (Rajan and Zingales, 1998; Barone and Cingano, 2011).

Clearly, using US data we assume that the rank ordering of the share of compensation of ICT in US industries corresponds to the rank ordering of the technological dependence of the industries. We also assume that that rank ordering carries over to the rest of the countries in our sample. An observation supporting the latter assumption is that the share of compensation of ICT capital is constant in a steady state equilibrium. Therefore, much of the variation within industries may arise from transitory shocks that would change the relative demand for ICT capital. As long as, however, these shocks are common in OECD countries and there is technological and regulatory convergence across these countries, the measure constructed from US data would be a good proxy.

Our (industry-level) data for ICT capital compensation and value added have a time span of 2005-2007. We take the ratio of these two and average the ratio over the period 2005-2007. We use this average as a measure for ICT dependence. ${ }^{6}$

\subsubsection{Investments in ICT and Remaining Industry-level Variables}

We follow the theoretical model and construct the industry-level measure of ICT investment as the ratio of nominal investments in ICT and value added averaged over 2005-2007 period. Further, for

${ }^{5}$ The consumption of communication services tends to exhibit strong differences between the period before financial crisis and the period of financial crisis.

${ }^{6}$ We perform a simple ANOVA exercise for the share of ICT capital compensation in US industries for an extended period of 2000-2007. This exercise suggests that industry-level variation accounts for 96.5 percent of the total variation. 
an industry, we use the average growth of TFP during this period to proxy for the expected TFP growth.

To measure interest rate, we use data for industry rate of return on capital. We also obtain data for real ICT capital stock and use in our analysis the ratio of this stock and real value added in an industry (both are in 1995 prices). The rate of return on capital and this ratio are from 2005 and are predetermined from the perspective of our analysis. Table 1 summarizes these variables.

In order to carry out separate analysis for investments in information technologies, communication technologies, and software, we compute variables in exact analogy to the variables for aggregate ICT. We use labels IT, CT, and Software, to differentiate them. Table 2 offers summary statistics of all industry-level variables.

\subsubsection{Doing Business Indicators}

We use five broad categories of regulation of business activities: regulations of starting business, property registration, getting credit, protecting investors, and paying taxes. The data for these regulations are from the World Bank's Doing Business database. These data are based on studies of legal system and regulations, and surveys of lawyers. The variables which we use, together with their descriptions, are presented in Table 3.

These variables are better proxies for regulation of business activities than other usually available perceptions-based measures (Djankov et al, 2006). In this regard, using a sample of OECD countries, arguably, allows us to limit the possibility of disconnect between existence and implementation of regulations.

We use observations of these variables from 2005, where available. Variables related to regulation of investor protection and paying taxes are available from 2006. We use values from 2006 for them. ${ }^{7}$ The use of values from 2006 may exacerbate reverse causality concerns. However, since these variables display little variation over short periods of time, most likely this is not a significant issue. ${ }^{8}$ Table 4 offers summary statistics of these variables. ${ }^{9}$

\section{Results}

The first column of Table 5 offers our main results $\left(\hat{\beta}_{1}\right)$ from estimation of the specification (9). The dependent variable is ICT investment, and the interaction terms consist of the measure of dependence on ICT and regulatory variables. Given that the dependent variable is from the interval $[0,1]$, we use censored Tobit estimation method, with robust (clustered) standard errors. Moreover, in all regressions we exclude the top and the bottom percentiles of the dependent variable as outliers.

The results suggest that investments in ICT are lower in industries that depend more on ICT in countries with a greater number of procedures, time, and monetary cost required for starting a business, and procedures and time required for registering property. Moreover, investments in ICT are lower in countries with a greater number of tax payments and time required to pay taxes. Investments are higher, however, in countries with legal rights systems which facilitate lending. For

\footnotetext{
${ }^{7}$ Variables related to starting business are available from 2004.

${ }^{8} \mathrm{~A}$ simple ANOVA exercise performed on these variables suggests that country-level variation explains $82.8-99.0$ percent of the total variation. In turn, time variation explains only 0-2.9 percent.

${ }^{9}$ Online Appendix - Data offers the correlations among country- and industry-level variables and additional basic statistics.
} 
the remaining regulatory variables, although the coefficients on interaction term are not statistically significant, they tend to have plausible signs. All in all, this evidence suggests that the costs of starting business, registering property, and paying taxes reduce ICT investment and better legal rights systems increase it.

Since we have a difference-in-differences estimator, one way to compute the magnitude of our results is as follows. We take the countries that rank the lowest and the top in terms of the regulatory variables and compute the difference between the levels of these variables for them. Further, we take the industries that rank the lowest and the highest in terms of the level of dependence on ICT and compute the difference between dependence levels. In our sample, these industries are Real Estate Activities (lowest dependence) and Financial Intermediation (highest dependence). Finally, we compute

$\hat{\beta}_{1} \times \Delta \mathrm{ICT}$ Dependence $\times \Delta$ Regulation,

where $\Delta$ stands for the difference operator between the lowest and the highest levels. The last column of Table 5 reports these effects for each regression. Focusing on statistically significant estimates of $\beta_{1}$, the computed effects are in-between $0.016-0.028$. These numbers correspond to the effect of moving from the top country to the bottom in terms of the doing business regulations on ICT investment (relative to value added) in highest dependence industry relative to the lowest dependence industry. All these numbers suggest that regulations of doing business have economically large and significant effects at least relative to the mean of ICT investment which is 0.023 . Admittedly, these are the largest effects of regulations according to our estimations. ${ }^{10}$

\subsection{Results for the Components of ICT}

There is evidence showing that the investments in the components of ICT, information technologies, communication technologies, and software, have varying effects on aggregate performance (Jorgenson and Stiroh, 2000). In the light of this evidence, we test whether regulations of doing business have different effects on investments in information technologies, communication technologies, and software.

Tables $6-8$ report our results from the estimations of the specification (9), where the dependent variables are investments in information technologies (IT), communication technologies (CT), and software, relative to value added. The interaction terms consist of business regulation variables and measures of dependence on IT, CT, and software. Similarly to ICT dependence, we use the shares of compensation of computing equipment, communications equipment, and software capital in nominal value added in US industries to measure dependence levels. Estimation method is Tobit with $[0,1]$ censoring and robust (clustered) standard errors.

The results for investments in information technologies, communication technologies, and software, are quite similar to our results for aggregate ICT, with a few notable exceptions. Lower monetary costs for registering property significantly increase investments in information technologies and software. Investments in software also increase with the ability of shareholders to sue the directors and officers for misconduct. In turn, the greater liability of directors for self-dealing reduces investments in communication technologies. However, we fail to establish any systematic evidence that the number of tax payments and the time required to compile taxes affect invest-

\footnotetext{
${ }^{10}$ In an attempt of ruling out other explanations for our results, we perform various robustness checks and offer the results in Online Appendix - Robustness Checks.
} 
ments in communication technologies. Higher tax rate reduces investments in software but does not affect investments in IT and CT.

A potential explanation why director liability can reduce investments in communication technologies can be that investments in these technologies, in industries that depend more on them, are relatively large scale projects and might require risk taking. Therefore, higher liability might scare investments. We neither have data nor intend to test these conjectures in this paper. Admittedly, further research in this direction might be valuable.

\section{Conclusions}

Investments in ICT significantly contribute to economic growth and development according to recent empirical evidence. In this paper, we investigate how the regulations of business activities affect investments in ICT. All in all, our results suggest that these regulations have significant and economically sizable effects. We find that reducing the number of procedures, time, and costs required for starting business and time and procedures required for registering property increases investments in ICT. We also find that reducing the number of tax payments, time required for compiling tax payments, and strengthening legal rights, increases investments in ICT. Moreover, according to our results, lower monetary costs of registering private property imply higher investments in information technologies, and greater ability of shareholders to sue the directors and officers for misconduct imply higher investments in software. In turn, lesser extent of director liability implies higher investments in communication technologies, and lower tax rate implies higher investments in software.

Recently, many developed and developing countries have instituted policy agendas which aim to increase investments in ICT (e.g., Digital Agenda in Europe, National Digital Economy Strategy in Australia, and eReadiness Initiatives in Pakistan). Our results suggest possible policy instruments which can motivate investments in ICT and its components and complement such policy agendas. 


\section{Acknowledgements}

We would like to thank two anonymous referees, Montserrat Vilalta-Bufi, Xavier Raurich, Fernando Sánchez-Losada, Sophia Dimelis, and seminar participants at the Arnoldshain Seminar XII in Valencia (2014) and the Armenian Economic Association Meeting in Yerevan (2014) for thoughtful comments. Vahagn Jerbashian acknowledges the financial support from the Spanish Ministry of Education and Science through grant ECO2012-34046 and the Generalitat of Catalonia through grant 2014SGR493. All errors remain our own.

\section{References}

Acemoglu D, Johnson S, Robinson JA (2001) The colonial origins of comparative development: An empirical investigation. The American Economic Review 91(5):1369-1401

Alesina A, Ardagna S, Nicoletti G, Schiantarelli F (2005) Regulation and investment. Journal of the European Economic Association 3(4):791-825

Amin M, Haidar JI (2012) The cost of registering property: Does legal origin matter? Empirical Economics 42(3):1035-1050

Andonova V, Diaz-Serrano L (2009) Political institutions and telecommunications. Journal of Development Economics 89(1):77-83

Barone G, Cingano F (2011) Service regulation and growth: Evidence from OECD countries. The Economic Journal 121(555):931-957

Barseghyan L (2008) Entry costs and cross-country differences in productivity and output. Journal of Economic Growth 13(2):145-167

Bena J, Ondko P, Vourvachaki E (2011) Productivity gains from services liberalization in Europe. CERGE-EI Working Papers, wp 452

Branstetter L, Lima F, Taylor LJ, Venâncio A (2014) Do entry regulations deter entrepreneurship and job creation? Evidence from recent reforms in Portugal. The Economic Journal 124(577):805832

Carlin W, Mayer C (2003) Finance, investment, and growth. Journal of Financial Economics 69(1):191-226

Claessens S, Laeven L (2003) Financial development, property rights, and growth. The Journal of Finance 58(6):2401-2436

Djankov S (2009) The regulation of entry: A survey. World Bank Research Observer 24(2):183-203

Djankov S, McLiesh C, Ramalho RM (2006) Regulation and growth. Economics Letters 92(3):395401

Grajek M, Röller LH (2012) Regulation and investment in network industries: Evidence from European telecoms. Journal of Law and Economics 55(1):189-216

Gruber H, Verboven F (2001) The diffusion of mobile telecommunications services in the European Union. European Economic Review 45(3):577-588

Gust C, Marquez J (2004) International comparisons of productivity growth: The role of information technology and regulatory practices. Labour Economics 11(1):33-58

Haidar JI (2009) Investor protections and economic growth. Economics Letters 103(1):1-4

Haidar JI (2012) The impact of business regulatory reforms on economic growth. Journal of the Japanese and International Economies 26(3):285-307 
Heli K, Kretschmer T (2005) Entry, standards and competition: Firm strategies and the diffusion of mobile telephony. Review of Industrial Organization 26(1):89-113

Jorgenson DW, Stiroh KJ (2000) Raising the speed limit: U.S. economic growth in the information age. In: Jorgenson DW, Stiroh KJ, Gordon RJ, Sichel DE (eds) Brookings Papers on Economic Activity, Brookings Institution Press, pp 125-235

Jorgenson DW, Ho MS, Stiroh KJ (2005) Information technology and the American growth resurgence. MIT Press, Cambridge, MA

Ketteni E, Mamuneas TP, Stengos T (2007) Nonlinearities in economic growth: A semiparametric approach applied to information technology data. Journal of Macroeconomics 29(3):555-568

Ketteni E, Mamuneas TP, Stengos T (2011) The effect of information technology and human capital on economic growth. Macroeconomic Dynamics 15(5):595-615

Klapper L, Laeven L, Rajan RG (2006) Entry regulation as a barrier to entrepreneurship. Journal of Financial Economics 82(3):591-629

Nardotto M, Valletti T, Verboven F (2012) Unbundling the incumbent: Evidence from UK broadband. CEPR Discussion Papers, dp 9194

Rajan RG, Zingales L (1998) Financial dependence and growth. The American Economic Review 88(3):559-586

Venturini F (2009) The long-run impact of ICT. Empirical Economics 37(3):497-515 


\section{Tables}

Table 1: Description of Industry-level Variables

\begin{tabular}{|c|c|}
\hline Variable Name & Description \\
\hline ICT Investment & $\begin{array}{l}\text { Nominal investment in ICT divided to nominal value added and averaged over the } \\
\text { period 2005-2007. Both variables are in national currency units (in EUR in the } \\
\text { Czech Republic). }\end{array}$ \\
\hline ICT Dependence & $\begin{array}{l}\text { ICT capital compensation in US industries divided to nominal value added and } \\
\text { averaged over the period 2005-2007. Both variables are in national currency units } \\
\text { (in EUR in the Czech Republic). }\end{array}$ \\
\hline$K_{I C T}$ & $\begin{array}{l}\text { Real ICT capital stock divided to real value added in } 2005 \text {. Both variables are in } \\
1995 \text { prices. }\end{array}$ \\
\hline$r$ & Industry rate of return on capital in 2005 . \\
\hline$g_{A}$ & The contribution of TFP to value added growth averaged over the period $2005-2007$. \\
\hline
\end{tabular}

Sample Industries (1- and 2-digit ISIC rev. 3; EU KLEMS): AtB, C, E, F, H, J, N, O, 15t16, 17t19, 20, 21t22, 23, 24, 25, 26, 27t28, 29, 30t33, 34t35, 36t37, 50, 51, 52, 60t63, 70, and 71t74.

Table 2: Summary Statistics - Industry-level Variables

\begin{tabular}{lccccc}
\hline \hline & $\mathrm{N}$ & $\mathrm{Mean}$ & $\mathrm{SD}$ & $\mathrm{Min}$ & $\mathrm{Max}$ \\
\hline ICT Investment & 364 & 0.023 & 0.018 & 0.001 & 0.138 \\
ICT Dependence & 27 & 0.047 & 0.028 & 0.005 & 0.099 \\
$K_{I C T}$ & 364 & 0.259 & 1.057 & 0.002 & 20.090 \\
IT Investment & 364 & 0.007 & 0.006 & 0.000 & 0.050 \\
IT Dependence & 27 & 0.010 & 0.008 & 0.001 & 0.042 \\
$K_{I T}$ & 364 & 0.130 & 0.179 & 0.000 & 2.314 \\
CT Investment & 364 & 0.003 & 0.005 & 0.000 & 0.044 \\
CT Dependence & 27 & 0.008 & 0.012 & 0.002 & 0.062 \\
$K_{C T}$ & 364 & 0.080 & 0.838 & 0.000 & 15.995 \\
Software Investment & 364 & 0.012 & 0.012 & 0.000 & 0.109 \\
Software Dependence & 27 & 0.029 & 0.019 & 0.002 & 0.076 \\
$K_{\text {Software }}$ & 364 & 0.044 & 0.098 & 0.000 & 1.781 \\
$r$ & 378 & 0.140 & 0.156 & -0.650 & 1.195 \\
$g_{A}$ & 378 & 0.012 & 0.062 & -0.467 & 0.445 \\
\hline \hline
\end{tabular}

Note: This table shows the descriptive statistics of industry-level variables. The data are from the EU KLEMS database. See Table 1 and the main text for the descriptions of variables. The definitions of variables related to IT, CT, and Software are identical to the definitions of variables related to ICT.

Table 3: Description of the Variables from the Doing Business Database

\begin{tabular}{ll}
\hline \hline Variable Name & Description \\
\hline Regulations of Starting Business \\
Entry Procedures & $\begin{array}{l}\text { Number of procedures that are officially required for starting a business (out of } \\
100) .\end{array}$ \\
Entry Time & Number of months (31 calendar days) necessary to complete all procedures that are \\
& officially required for starting a business. \\
\hline
\end{tabular}


Table 3 - (Continued)

\begin{tabular}{|c|c|}
\hline Variable Name & Description \\
\hline Entry Cost & $\begin{array}{l}\text { Monetary costs of completing all procedures that are officially required for starting } \\
\text { a business (percentage of per capita income). }\end{array}$ \\
\hline Minimum Capital & $\begin{array}{l}\text { Measures the amount that entrepreneurs need to deposit in a bank (or with a notary) } \\
\text { before registration and up to } 3 \text { months following incorporation (percentage of per } \\
\text { capita income). }\end{array}$ \\
\hline \multicolumn{2}{|c|}{ Regulations of Property Registration } \\
\hline Property Procedures & $\begin{array}{l}\text { Number of procedures that are legally required for registering property transfers } \\
\text { (out of 100). }\end{array}$ \\
\hline Property Time & $\begin{array}{l}\text { Number of months ( } 31 \text { calendar days) necessary for completing all procedures that } \\
\text { are legally required for registering property transfers. }\end{array}$ \\
\hline Property Cost & $\begin{array}{l}\text { Monetary costs of completing all procedures that are legally required for registering } \\
\text { property (percentage of the property value). }\end{array}$ \\
\hline \multicolumn{2}{|c|}{ Regulations of Getting Credit } \\
\hline Legal Rights & $\begin{array}{l}\text { Measures whether laws of collateral and bankruptcy provide for features that facil- } \\
\text { itate lending ( } 0 \text { to } 1 \text { index). }\end{array}$ \\
\hline Credit Info & $\begin{array}{l}\text { Measures rules affecting the access and quality of credit information available } \\
\text { through public and/or private credit registries ( } 0 \text { to } 1 \text { index). }\end{array}$ \\
\hline \multicolumn{2}{|c|}{ Regulations of Investor Protection } \\
\hline Business Disclosure & $\begin{array}{l}\text { Measures whether laws provide for ways of enhancing transparency of related-party } \\
\text { transactions ( } 0 \text { to } 1 \text { index). }\end{array}$ \\
\hline Director Liability & Measures the extent director liability for self-dealing ( 0 to 1 index). \\
\hline Ease of Suits & $\begin{array}{l}\text { Measures the ability of shareholders to sue directors and officers for misconduct ( } 0 \\
\text { to } 1 \text { index). }\end{array}$ \\
\hline \multicolumn{2}{|l|}{ Tax System } \\
\hline Tax Number & Measures the total number of taxes and contributions paid (out of 100). \\
\hline Tax Time & $\begin{array}{l}\text { Number of months ( } 31 \text { calendar days) taken to compile and pay } 3 \text { major types of } \\
\text { taxes and contributions: the corporate income tax, value added/sales tax, and labor } \\
\text { taxes. }\end{array}$ \\
\hline Tax Rate & $\begin{array}{l}\text { Measures the amount of taxes and mandatory contributions borne by the business } \\
\text { (percentage of commercial profit). }\end{array}$ \\
\hline
\end{tabular}

Sample Countries: Australia, Austria, the Czech Republic, Denmark, Finland, Germany, Italy, Japan, Slovenia, Spain, Sweden, the Netherlands, the UK, and the US. 
Table 4: Summary Statistics - Country-level Variables

\begin{tabular}{lcccc}
\hline \hline & Mean & SD & Min & Max \\
\hline Entry Procedures & 0.071 & 0.028 & 0.030 & 0.110 \\
Entry Time & 0.912 & 0.962 & 0.097 & 3.677 \\
Entry Cost & 0.074 & 0.070 & 0.000 & 0.214 \\
Minimum Capital & 0.329 & 0.258 & 0.000 & 0.749 \\
Property Procedures & 0.046 & 0.013 & 0.020 & 0.060 \\
Property Time & 1.810 & 3.252 & 0.177 & 12.613 \\
Property Cost & 0.039 & 0.021 & 0.005 & 0.087 \\
Legal Rights & 0.700 & 0.184 & 0.300 & 1 \\
Credit Info & 0.833 & 0.173 & 0.500 & 1 \\
Business Disclosure & 0.550 & 0.238 & 0.200 & 1 \\
Director Liability & 0.529 & 0.182 & 0.200 & 0.900 \\
Ease of Suits & 0.679 & 0.137 & 0.400 & 0.900 \\
Tax Number & 0.139 & 0.064 & 0.040 & 0.270 \\
Tax Time & 8.806 & 6.672 & 3.387 & 30 \\
Tax Rate & 0.502 & 0.111 & 0.333 & 0.768 \\
\hline \hline
\end{tabular}

Note: This table shows the descriptive statistics of county-level variables. The number of country-level observations is 14 , and the data are from the Word Bank's Doing Business database. Variables related to investor protection and paying taxes are from 2006. The remaining variables are from 2005. See Table 3 and the main text for the descriptions of variables.

Table 5: Regression Results for ICT Investment

\begin{tabular}{|c|c|c|c|c|c|c|c|c|c|}
\hline \multirow{2}{*}{$\begin{array}{c}\text { Regulation } \\
\text { Entry Procedures }\end{array}$} & \multicolumn{2}{|c|}{$\begin{array}{l}\text { ICT Dependence } \times \\
\text { Regulation }\end{array}$} & \multicolumn{2}{|c|}{$K_{I C T}$} & \multicolumn{2}{|c|}{$r$} & \multicolumn{2}{|c|}{$g_{A}$} & \multirow{2}{*}{$\begin{array}{l}\text { Max. } \\
\text { Effect } \\
-0.024\end{array}$} \\
\hline & $-3.117^{* * *}$ & $(1.089)$ & 0.001 & $(0.001)$ & $-0.012 * *$ & $(0.005)$ & $-0.029 * *$ & $(0.014)$ & \\
\hline Entry Time & $-0.064 * *$ & $(0.031)$ & 0.001 & $(0.001)$ & $-0.011 * *$ & $(0.006)$ & $-0.031^{* *}$ & $(0.015)$ & -0.022 \\
\hline Entry Cost & $-1.319 * * *$ & $(0.409)$ & 0.001 & $(0.001)$ & $-0.013^{* *}$ & $(0.005)$ & $-0.031 * *$ & $(0.015)$ & -0.027 \\
\hline Minimum Capital & -0.011 & $(0.100)$ & 0.001 & $(0.001)$ & $-0.011 * *$ & $(0.006)$ & $-0.032 * *$ & $(0.016)$ & -0.001 \\
\hline Property Procedures & $-4.545^{*}$ & $(2.603)$ & 0.001 & $(0.001)$ & $-0.012^{* *}$ & $(0.005)$ & $-0.032^{* *}$ & $(0.015)$ & -0.017 \\
\hline Property Time & $-0.019 * * *$ & $(0.005)$ & $0.001^{*}$ & $(0.001)$ & $-0.011^{*}$ & $(0.006)$ & $-0.032 * *$ & $(0.015)$ & -0.022 \\
\hline Property Cost & -2.257 & $(1.564)$ & 0.001 & $(0.001)$ & $-0.012 * *$ & $(0.006)$ & $-0.031 * *$ & $(0.016)$ & -0.017 \\
\hline Legal Rights & $0.240^{*}$ & $(0.135)$ & 0.001 & $(0.001)$ & $-0.011 * *$ & $(0.006)$ & $-0.032^{* *}$ & $(0.016)$ & 0.016 \\
\hline Credit Info & -0.072 & $(0.175)$ & 0.001 & $(0.001)$ & $-0.012 * *$ & $(0.006)$ & $-0.032 * *$ & $(0.016)$ & -0.003 \\
\hline Business Disclosure & -0.014 & $(0.127)$ & 0.001 & $(0.001)$ & $-0.011^{*}$ & $(0.006)$ & $-0.032^{* *}$ & $(0.016)$ & -0.001 \\
\hline Director Liability & 0.093 & $(0.168)$ & 0.001 & $(0.001)$ & $-0.011 * *$ & $(0.006)$ & $-0.033^{* *}$ & $(0.016)$ & 0.006 \\
\hline Ease of Suits & 0.253 & $(0.203)$ & 0.001 & $(0.001)$ & $-0.012^{* *}$ & $(0.006)$ & $-0.031 * *$ & $(0.016)$ & 0.012 \\
\hline Tax Number & $-1.304 * * *$ & $(0.391)$ & 0.001 & (0.001) & $-0.010^{*}$ & $(0.006)$ & $-0.032 * *$ & $(0.016)$ & -0.028 \\
\hline Tax Time & $-0.007 * * *$ & $(0.003)$ & 0.001 & $(0.001)$ & $-0.011 * *$ & $(0.006)$ & $-0.032^{* *}$ & $(0.015)$ & -0.019 \\
\hline Tax Rate & -0.399 & $(0.246)$ & 0.001 & $(0.001)$ & $-0.012^{* *}$ & $(0.006)$ & $-0.033 * *$ & $(0.016)$ & -0.016 \\
\hline
\end{tabular}

Note: This table reports the results from estimation of the specification (9), where the dependent variable is ICT Investment. The last column reports the maximum effects of regulations. The estimation method is Tobit with [0,1] censoring. All regressions include industry and country dummies. The number of observations is 364 , and F-statistics vary from 13.18 to 16.54. Robust (clustered) standard errors are in parentheses. $* * *$ indicates significance at the $1 \%$ level, $* *$ at the $5 \%$ level, and $*$ at the $10 \%$ level. 
Table 6: Regression Results for IT Investment

\begin{tabular}{|c|c|c|c|c|c|c|c|c|c|}
\hline \multirow{2}{*}{$\begin{array}{c}\text { Regulation } \\
\text { Entry Procedures }\end{array}$} & \multicolumn{2}{|c|}{$\begin{array}{l}\text { IT Dependence } \times \\
\text { Regulation }\end{array}$} & \multicolumn{2}{|c|}{$K_{I T}$} & \multicolumn{2}{|c|}{$r$} & \multicolumn{2}{|c|}{$g_{A}$} & \multirow{2}{*}{$\begin{array}{c}\text { Max. } \\
\text { Effect }\end{array}$} \\
\hline & $-3.298^{* * *}$ & $(0.839)$ & $0.013^{* *}$ & $(0.006)$ & -0.001 & $(0.001)$ & 0.000 & $(0.010)$ & \\
\hline Entry Time & $-0.065 * *$ & $(0.026)$ & $0.013^{* *}$ & $(0.006)$ & -0.002 & $(0.001)$ & 0.000 & $(0.010)$ & -0.009 \\
\hline Entry Cost & $-1.770 * * *$ & $(0.447)$ & $0.013^{* *}$ & $(0.006)$ & -0.002 & $(0.001)$ & 0.000 & $(0.010)$ & -0.015 \\
\hline Minimum Capital & -0.057 & $(0.111)$ & $0.013^{* *}$ & $(0.006)$ & -0.002 & $(0.001)$ & -0.001 & $(0.010)$ & -0.002 \\
\hline Property Procedures & $-4.249^{*}$ & $(2.321)$ & $0.013^{* *}$ & $(0.006)$ & -0.001 & $(0.001)$ & -0.000 & $(0.010)$ & -0.007 \\
\hline Property Time & $-0.032 * *$ & $(0.014)$ & $0.013^{* *}$ & $(0.006)$ & -0.002 & $(0.001)$ & 0.000 & $(0.010)$ & -0.016 \\
\hline Property Cost & $-2.690 * *$ & $(1.160)$ & $0.013^{* *}$ & $(0.006)$ & -0.002 & $(0.001)$ & 0.000 & $(0.011)$ & -0.009 \\
\hline Legal Rights & $0.378^{* *}$ & $(0.180)$ & $0.013^{* *}$ & $(0.006)$ & -0.002 & $(0.001)$ & -0.000 & $(0.010)$ & 0.011 \\
\hline Credit Info & -0.127 & $(0.186)$ & $0.013^{* *}$ & $(0.006)$ & -0.002 & $(0.001)$ & -0.001 & $(0.011)$ & -0.003 \\
\hline Business Disclosure & 0.041 & $(0.162)$ & $0.013^{* *}$ & $(0.006)$ & -0.002 & $(0.001)$ & -0.000 & $(0.010)$ & 0.001 \\
\hline Director Liability & -0.164 & $(0.157)$ & $0.013^{* *}$ & $(0.006)$ & -0.002 & $(0.001)$ & -0.000 & $(0.010)$ & -0.005 \\
\hline Ease of Suits & 0.258 & $(0.164)$ & $0.013^{* *}$ & $(0.006)$ & $-0.002^{*}$ & $(0.001)$ & -0.000 & $(0.011)$ & 0.005 \\
\hline Tax Number & $-1.735^{* * *}$ & $(0.624)$ & $0.013^{* *}$ & $(0.006)$ & -0.002 & $(0.001)$ & -0.000 & $(0.010)$ & -0.016 \\
\hline Tax Time & $-0.013^{* *}$ & $(0.005)$ & $0.013^{* *}$ & $(0.006)$ & -0.002 & $(0.001)$ & -0.000 & $(0.010)$ & -0.014 \\
\hline Tax Rate & -0.368 & $(0.259)$ & $0.013^{* *}$ & $(0.006)$ & $-0.002^{*}$ & $(0.001)$ & -0.001 & $(0.011)$ & -0.007 \\
\hline
\end{tabular}

Note: This table reports the results from estimation of the specification (9), where the dependent variable is IT Investment. The last column reports the maximum effects of regulations. The estimation method is Tobit with [0,1] censoring. All regressions include industry and country dummies. The number of observations is 364 , and F-statistics vary from 18.79 to 21.83. Robust (clustered) standard errors are in parentheses. $* * *$ indicates significance at the $1 \%$ level, $* *$ at the $5 \%$ level, and $*$ at the $10 \%$ level.

Table 7: Regression Results for CT Investment

\begin{tabular}{|c|c|c|c|c|c|c|c|c|c|}
\hline \multirow{2}{*}{$\begin{array}{c}\text { Regulation } \\
\text { Entry Procedures }\end{array}$} & \multicolumn{2}{|c|}{$\begin{array}{l}\text { CT Dependence } \times \\
\text { Regulation }\end{array}$} & \multicolumn{2}{|c|}{$K_{C T}$} & \multicolumn{2}{|c|}{$r$} & \multicolumn{2}{|c|}{$g_{A}$} & \multirow{2}{*}{$\begin{array}{l}\text { Max. } \\
\text { Effect }\end{array}$} \\
\hline & $-1.972^{* *}$ & $(1.004)$ & $0.000 *$ & $(0.000)$ & $-0.004 * * *$ & $(0.001)$ & $-0.006 * *$ & $(0.003)$ & \\
\hline Entry Time & $-0.081 * * *$ & $(0.031)$ & $0.000^{*}$ & $(0.000)$ & $-0.004^{* * *}$ & $(0.001)$ & $-0.006^{* *}$ & $(0.003)$ & -0.018 \\
\hline Entry Cost & $-0.913^{* *}$ & $(0.426)$ & $0.000^{*}$ & $(0.000)$ & $-0.004 * * *$ & $(0.001)$ & $-0.006 * *$ & $(0.003)$ & -0.012 \\
\hline Minimum Capital & -0.065 & $(0.080)$ & $0.000 * *$ & $(0.000)$ & $-0.004 * * *$ & $(0.001)$ & $-0.006 * *$ & $(0.003)$ & -0.003 \\
\hline Property Procedures & -2.587 & $(2.944)$ & $0.000^{*}$ & $(0.000)$ & $-0.004^{* * *}$ & $(0.001)$ & $-0.006^{* *}$ & $(0.003)$ & -0.006 \\
\hline Property Time & $-0.010 * *$ & $(0.004)$ & $0.000^{*}$ & $(0.000)$ & $-0.004^{* * *}$ & $(0.001)$ & $-0.006^{* *}$ & $(0.003)$ & -0.007 \\
\hline Property Cost & 0.035 & $(1.591)$ & $0.000 * *$ & $(0.000)$ & $-0.005 * * *$ & $(0.001)$ & $-0.006^{* *}$ & $(0.003)$ & 0.000 \\
\hline Legal Rights & $0.282^{*}$ & $(0.161)$ & $0.000^{*}$ & $(0.000)$ & $-0.004^{* * *}$ & $(0.001)$ & $-0.006 * *$ & $(0.003)$ & 0.012 \\
\hline Credit Info & -0.025 & $(0.132)$ & $0.000 * *$ & $(0.000)$ & $-0.005 * * *$ & $(0.001)$ & $-0.006^{* *}$ & $(0.003)$ & -0.001 \\
\hline Business Disclosure & 0.091 & $(0.090)$ & $0.000 * *$ & $(0.000)$ & $-0.004 * * *$ & $(0.001)$ & $-0.006^{* *}$ & $(0.003)$ & 0.004 \\
\hline Director Liability & $-0.276^{* *}$ & $(0.118)$ & $0.000^{*}$ & $(0.000)$ & $-0.004^{* * *}$ & $(0.001)$ & $-0.006 * *$ & $(0.003)$ & -0.012 \\
\hline Ease of Suits & 0.069 & $(0.181)$ & $0.000 * *$ & $(0.000)$ & $-0.005^{* * *}$ & $(0.001)$ & $-0.006^{* *}$ & $(0.003)$ & 0.002 \\
\hline Tax Number & 0.475 & $(0.439)$ & $0.000 * *$ & $(0.000)$ & $-0.005^{* * *}$ & $(0.001)$ & $-0.007 * *$ & $(0.003)$ & 0.007 \\
\hline Tax Time & -0.001 & $(0.002)$ & $0.000 * *$ & $(0.000)$ & $-0.004 * * *$ & $(0.001)$ & $-0.006^{* *}$ & $(0.003)$ & -0.002 \\
\hline Tax Rate & 0.137 & $(0.243)$ & $0.000 * *$ & $(0.000)$ & $-0.004^{* * *}$ & $(0.001)$ & $-0.006^{* *}$ & $(0.003)$ & 0.004 \\
\hline
\end{tabular}

Note: This table reports the results from estimation of the specification (9), where the dependent variable is CT Investment. The last column reports the maximum effects of regulations. The estimation method is Tobit with [0,1] censoring. All regressions include industry and country dummies. The number of observations is 364 , and F-statistics vary from 6.53 to 7.72. Robust (clustered) standard errors are in parentheses. *** indicates significance at the $1 \%$ level, ** at the $5 \%$ level, and $*$ at the $10 \%$ level. 
Table 8: Regression Results for Software Investment

\begin{tabular}{|c|c|c|c|c|c|c|c|c|c|}
\hline \multirow{2}{*}{$\begin{array}{c}\text { Regulation } \\
\text { Entry Procedures }\end{array}$} & \multicolumn{2}{|c|}{$\begin{array}{c}\text { Software Dependence } \times \\
\text { Regulation }\end{array}$} & \multicolumn{2}{|c|}{$K_{\text {Software }}$} & \multicolumn{2}{|c|}{$r$} & \multicolumn{2}{|c|}{$g_{A}$} & \multirow{2}{*}{$\begin{array}{l}\text { Max. } \\
\text { Effect } \\
-0.020\end{array}$} \\
\hline & $-3.347^{* * *}$ & $(1.216)$ & 0.007 & $(0.018)$ & -0.006 & $(0.004)$ & 0.024 & $(0.028)$ & \\
\hline Entry Time & $-0.088^{* * *}$ & $(0.020)$ & 0.007 & $(0.017)$ & -0.005 & $(0.004)$ & 0.024 & $(0.030)$ & -0.023 \\
\hline Entry Cost & $-1.337^{* * *}$ & $(0.368)$ & 0.007 & $(0.017)$ & -0.006 & $(0.004)$ & 0.023 & $(0.029)$ & -0.021 \\
\hline Minimum Capital & -0.061 & $(0.081)$ & 0.006 & $(0.018)$ & -0.004 & $(0.004)$ & 0.025 & $(0.030)$ & -0.003 \\
\hline Property Procedures & -4.429 & $(2.722)$ & 0.008 & $(0.018)$ & -0.005 & $(0.004)$ & 0.023 & $(0.028)$ & -0.013 \\
\hline Property Time & $-0.012^{*}$ & $(0.006)$ & 0.009 & $(0.018)$ & -0.005 & $(0.004)$ & 0.025 & $(0.030)$ & -0.012 \\
\hline Property Cost & $-4.658^{* * *}$ & (1.197) & 0.003 & $(0.017)$ & -0.006 & $(0.004)$ & 0.025 & $(0.029)$ & -0.028 \\
\hline Legal Rights & 0.142 & $(0.108)$ & 0.007 & $(0.018)$ & -0.005 & $(0.004)$ & 0.025 & $(0.031)$ & 0.007 \\
\hline Credit Info & -0.141 & $(0.175)$ & 0.005 & $(0.018)$ & -0.005 & $(0.004)$ & 0.025 & $(0.030)$ & -0.005 \\
\hline Business Disclosure & -0.051 & $(0.126)$ & 0.006 & $(0.018)$ & -0.005 & $(0.005)$ & 0.025 & $(0.030)$ & -0.003 \\
\hline Director Liability & 0.136 & $(0.149)$ & 0.005 & $(0.018)$ & -0.005 & $(0.004)$ & 0.025 & $(0.031)$ & 0.007 \\
\hline Ease of Suits & $0.522^{* * *}$ & $(0.150)$ & 0.004 & $(0.018)$ & -0.005 & $(0.004)$ & 0.026 & $(0.030)$ & 0.019 \\
\hline Tax Number & $-1.202^{* * *}$ & $(0.429)$ & 0.008 & $(0.018)$ & -0.004 & $(0.004)$ & 0.023 & $(0.029)$ & -0.021 \\
\hline Tax Time & $-0.005^{*}$ & $(0.003)$ & 0.006 & $(0.018)$ & -0.005 & $(0.004)$ & 0.024 & $(0.030)$ & -0.011 \\
\hline Tax Rate & $-0.395^{* *}$ & $(0.167)$ & 0.005 & $(0.018)$ & -0.006 & $(0.004)$ & 0.025 & $(0.031)$ & -0.013 \\
\hline
\end{tabular}

Note: This table reports the results from estimation of the specification (9), where the dependent variable is Software Investment. The last column reports the maximum effects of regulations. The estimation method is Tobit with [0,1] censoring. All regressions include industry and country dummies. The number of observations is 364 , and F-statistics vary from 11.59 to 14.18 . Robust (clustered) standard errors are in parentheses. $* * *$ indicates significance at the $1 \%$ level, $* *$ at the $5 \%$ level, and ${ }^{*}$ at the $10 \%$ level. 


\title{
Online Appendix to The Impact of Doing Business \\ Regulations on Investments In ICT
}

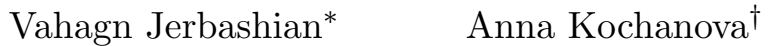

\section{Online Appendix - Data}

Table 9: Correlations - Industry-level Variables

\begin{tabular}{|c|c|c|c|c|c|}
\hline \multicolumn{6}{|c|}{ Information and Communication Technologies } \\
\hline & Variable & 1 & 2 & 3 & 4 \\
\hline 1 & ICT Investment & & & & \\
\hline 2 & ICT Dependence & $0.43^{* * *}$ & & & \\
\hline 3 & $K_{I C T}$ & $0.10^{*}$ & $0.11^{* *}$ & & \\
\hline 4 & $r$ & $0.11^{* *}$ & $0.28^{* * *}$ & -0.05 & \\
\hline 5 & $g_{A}$ & -0.00 & $0.13^{* * *}$ & $0.10^{* *}$ & $-0.09^{*}$ \\
\hline \multicolumn{6}{|c|}{ Information Technologies } \\
\hline & Variable & 1 & 2 & 3 & 4 \\
\hline 1 & IT Investment & & & & \\
\hline 2 & IT Dependence & $0.36^{* * *}$ & & & \\
\hline 3 & $K_{I T}$ & $0.60 * * *$ & $0.24^{* * *}$ & & \\
\hline 4 & $r$ & -0.05 & $0.39^{* * *}$ & -0.04 & \\
\hline 5 & $g_{A}$ & -0.00 & $0.09^{*}$ & $-0.11^{* *}$ & -0.04 \\
\hline \multicolumn{6}{|c|}{ Communication Technologies } \\
\hline & Variable & 1 & 2 & 3 & 4 \\
\hline 1 & CT Investment & & & & \\
\hline 2 & CT Dependence & $0.15^{* * *}$ & & & \\
\hline 3 & $K_{C T}$ & 0.07 & -0.01 & & \\
\hline 4 & $r$ & -0.05 & 0.04 & -0.06 & \\
\hline 5 & $g_{A}$ & $-0.13^{* *}$ & 0.01 & $0.13^{* *}$ & $-0.10^{*}$ \\
\hline \multicolumn{6}{|c|}{ Software } \\
\hline & Variable & 1 & 2 & 3 & 4 \\
\hline 1 & Software Investment & & & & \\
\hline 2 & Software Dependence & $0.32 * * *$ & & & \\
\hline 3 & $K_{\text {Software }}$ & $0.24^{* * *}$ & $0.19^{* * *}$ & & \\
\hline 4 & $r$ & 0.07 & $0.21^{* * *}$ & -0.02 & \\
\hline 5 & $g_{A}$ & $0.19 * * *$ & $0.15 * * *$ & $0.10^{*}$ & $-0.11^{* *}$ \\
\hline
\end{tabular}

Note: This table shows the pairwise correlations between industry-level variables. The data are from the EU KLEMS database. See Table 1 for the descriptions of variables. *** indicates significance at the $1 \%$ level, ** at the $5 \%$ level, and $*$ at the $10 \%$ level.

\footnotetext{
${ }^{*}$ University of Barcelona and CERGE-EI.

Address (corresponding author): University of Barcelona, Avenue Diagonal 696, 08034 Barcelona, Spain. Phone: +34934039081. E-mail: vahagn.jerbashian@ub.edu

${ }^{\dagger}$ Max Planck Institute for Research on Collective Goods.

CERGE-EI is a joint workplace of the Center for Economic Research and Graduate Education, Charles University in Prague, and the Economics Institute of Academy of Sciences of the Czech Republic.
} 


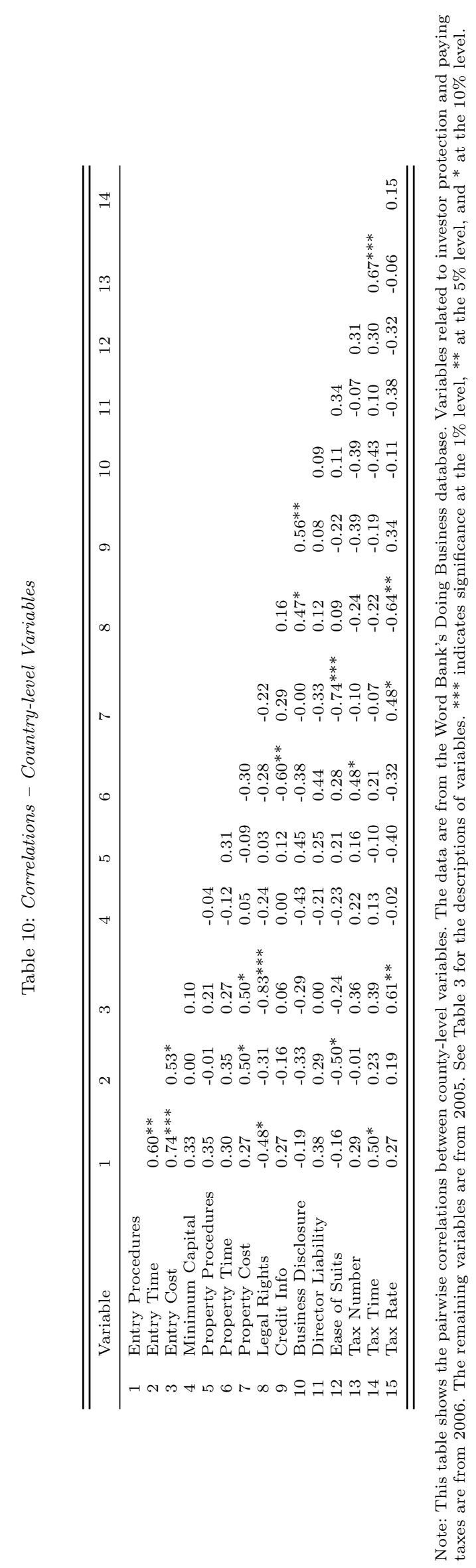




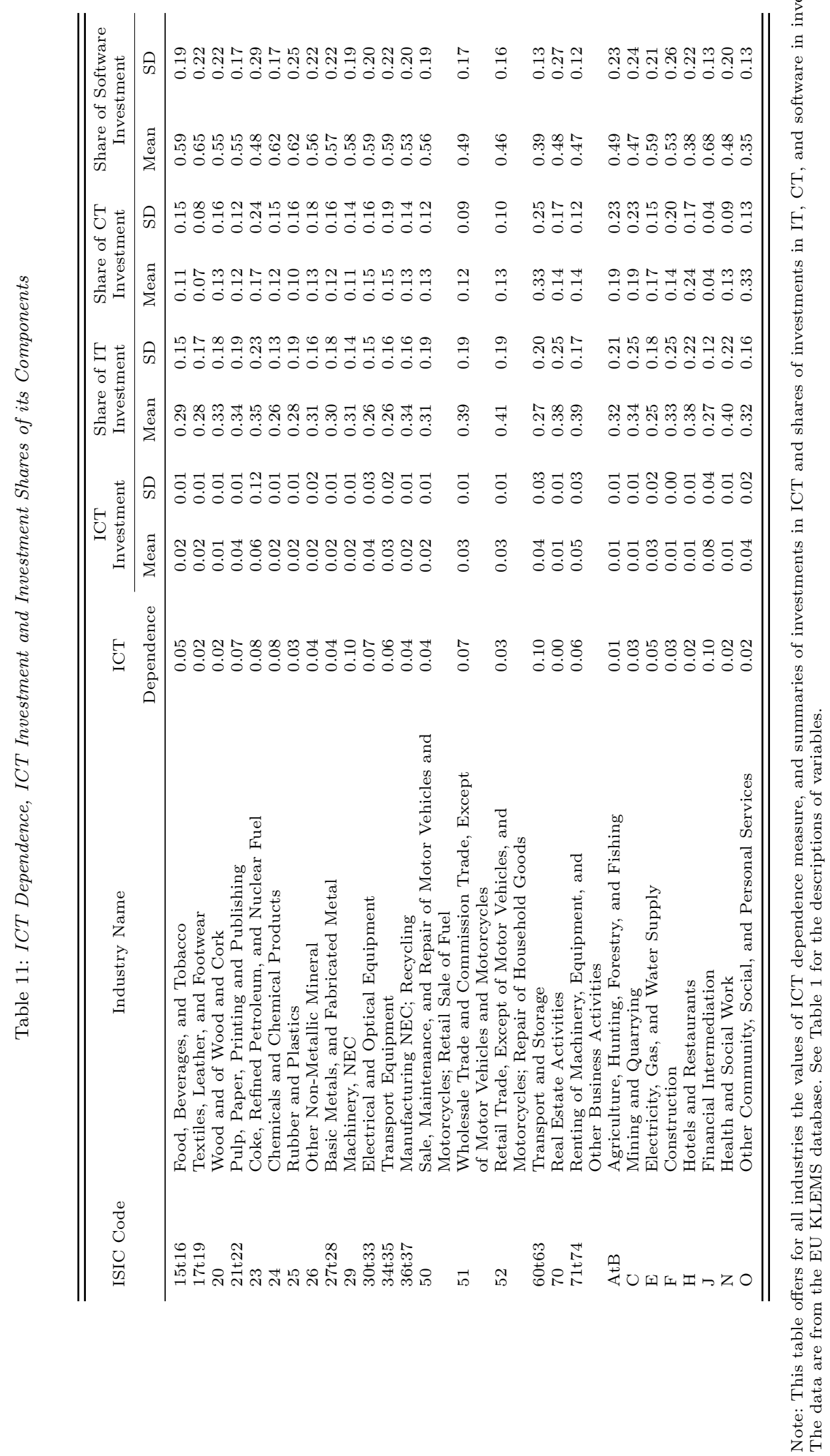




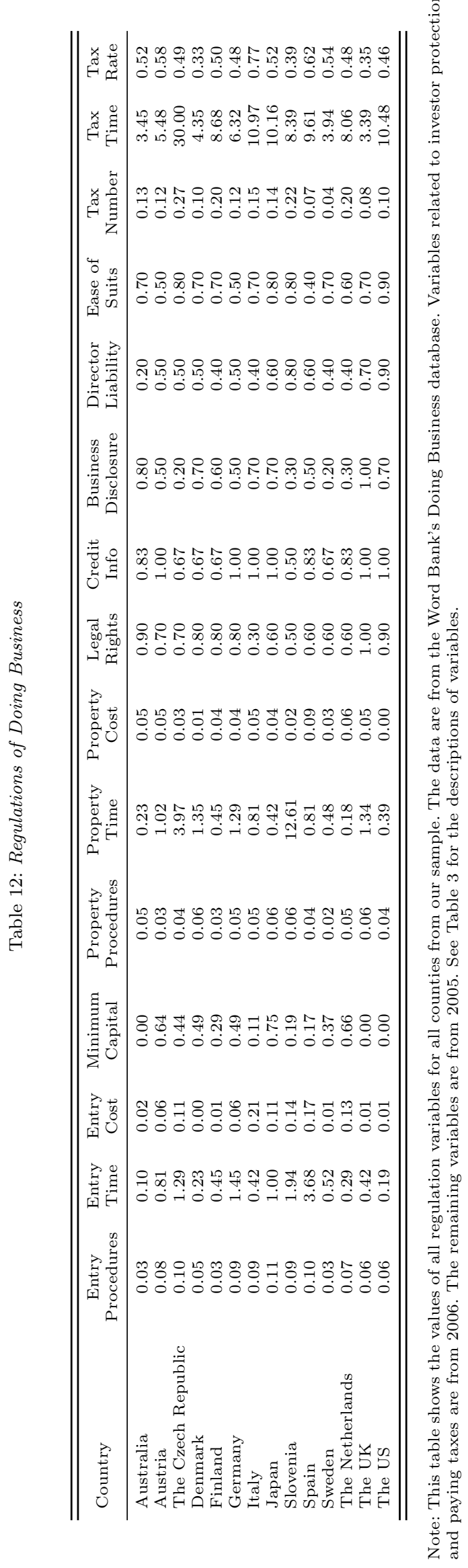




\section{Online Appendix - Robustness Checks}

In this appendix we present results from robustness check exercises. Table 13 presents results from estimation of the specification (9) using least squares method. In Table 14 we replace expected TFP growth rate with a measure of expected value added growth. To construct this measure, we subtract the contribution of ICT to value added growth from the growth rate of value added and average this difference over the period 2005-2007. In Table 15 we exclude the US from our estimation sample. In Table 16, we exclude in each country the industries which have relatively high levels of initial ICT capital. Further, our theoretical model suggests that the level of competition in industries can affect investment decisions. Moreover, the level of competition, in particular, in US industries can matter and confound our measure of ICT dependence. We use price-cost margin (PCM) to measure the level of competition. Price-cost margin is the empirical analogue of the Lerner index, and we define it as the ratio of total capital compensation to nominal output in each industry in countries of our sample. In Table 17 we include in the specification (9) the value of price-cost margin and its square measured in 2005. In Table 18 we include the interaction of regulatory variables with price-cost margin in US industries averaged over the period of 2005-2007 to take into account the possible confounding effect of competition level in US industries. In turn, in Table 19 we also include a measure of ICT capital specific interest rate. We construct this measure dividing ICT capital compensation to the price of value added and real ICT capital stock. The data for all these additional measures we obtain from the EU KLEMS database. Our results remain virtually intact. ${ }^{1}$

We use data from US industries to measure the technological dependence on ICT. It might be that this does not allow us to correctly measure the technological dependence of industries because the share of compensation of ICT capital in US industries differs from 'true' technological parameters by an idiosyncratic component. Our estimates would be subject to attenuation bias if such a component is purely random or unrelated to other determinants of investments in ICT. However, if it depends on the level of regulation, using US data could lead to a priori ambiguous biases in our estimation results. Clearly, similar concerns would hold if we attempted to identify ICT dependence using data from other countries in our sample. Our approach for alleviating these concerns consists of recovering a measure of ICT dependence not reflecting the share of compensation of ICT capital specific to a country, and using it as an instrument for ICT dependence identified from US data. We estimate one such measure for each regulation. First we regress the share of compensation of ICT capital in each country-industry pair $\omega_{i, c}$ on country dummies, industry dummies, and industry dummies interacted with the country-level regulation: $\omega_{i, c}=$ $\mu_{1, i}+\mu_{2, c}+\mu_{3, i} X_{c}+\nu_{i, c}$. Second, we estimate $\hat{\omega}_{i, \bar{c}}$ as the fitted values of $\omega_{i, c}$ setting countrylevel dummies to zero and regulations to their theoretically most desirable in sample values $\left(X_{\bar{c}}\right)$ : $\hat{\omega}_{i, \bar{c}}=\hat{\mu}_{1, i}+\hat{\mu}_{3, i} X_{\bar{c}}$. We select minimal in sample values for entry, property registration, and tax regulations and maximal in sample values for the remaining regulations. Therefore, $\hat{\omega}_{i, \bar{c}}$ does not reflect shares of ICT compensation that are country specific and can be used as instruments for ICT dependence identified from US data. ${ }^{2}$ The results obtained following this procedure are reported in Table 20. Statistically, they are almost identical to our earlier results although a few coefficients marginally gain in significance and a few coefficients loose it. ${ }^{3}$

\footnotetext{
${ }^{1}$ As a robustness check, we have also included in the specification (9) the share of an industry in a country in total industrial value added.

${ }^{2}$ Our approach is similar to the one of Barone and Cingano (2011) but we make no out of sample predictions.

${ }^{3}$ We implement similar robustness checks for the investments in information technologies, communication technologies, and software. These results are available upon request from the authors.
} 
Tables

Table 13: Robustness Check - Least Squares Estimation

\begin{tabular}{lllllllll}
\hline \multicolumn{1}{c}{ Regulation } & \multicolumn{2}{c}{$\begin{array}{c}\text { ICT Dependence } \\
\text { Regulation }\end{array}$} & \multicolumn{2}{c}{$K_{I C T}$} & \multicolumn{2}{c}{$r$} & & $g_{A}$ \\
\hline Entry Procedures & $-3.117^{* * *}$ & $(1.160)$ & 0.001 & $(0.001)$ & $-0.012^{* *}$ & $(0.005)$ & $-0.029^{*}$ & $(0.015)$ \\
Entry Time & $-0.064^{*}$ & $(0.033)$ & 0.001 & $(0.001)$ & $-0.011^{*}$ & $(0.006)$ & $-0.031^{*}$ & $(0.016)$ \\
Entry Cost & $-1.319^{* * *}$ & $(0.435)$ & 0.001 & $(0.001)$ & $-0.013^{* *}$ & $(0.006)$ & $-0.031^{*}$ & $(0.016)$ \\
Minimum Capital & -0.011 & $(0.107)$ & 0.001 & $(0.001)$ & $-0.011^{*}$ & $(0.006)$ & $-0.032^{*}$ & $(0.017)$ \\
Property Procedures & -4.545 & $(2.772)$ & 0.001 & $(0.001)$ & $-0.012^{* *}$ & $(0.006)$ & $-0.032^{* *}$ & $(0.016)$ \\
Property Time & $-0.019^{* * *}$ & $(0.005)$ & $0.001^{*}$ & $(0.001)$ & $-0.011^{*}$ & $(0.006)$ & $-0.032^{*}$ & $(0.016)$ \\
Property Cost & -2.257 & $(1.666)$ & 0.001 & $(0.001)$ & $-0.012^{* *}$ & $(0.006)$ & $-0.031^{*}$ & $(0.017)$ \\
Legal Rights & $0.240^{*}$ & $(0.144)$ & 0.001 & $(0.001)$ & $-0.011^{*}$ & $(0.006)$ & $-0.032^{*}$ & $(0.017)$ \\
Credit Info & -0.072 & $(0.186)$ & 0.001 & $(0.001)$ & $-0.012^{*}$ & $(0.006)$ & $-0.032^{*}$ & $(0.017)$ \\
Business Disclosure & -0.014 & $(0.136)$ & 0.001 & $(0.001)$ & $-0.011^{*}$ & $(0.006)$ & $-0.032^{*}$ & $(0.017)$ \\
Director Liability & 0.093 & $(0.179)$ & 0.001 & $(0.001)$ & $-0.011^{*}$ & $(0.006)$ & $-0.033^{*}$ & $(0.017)$ \\
Ease of Suits & 0.253 & $(0.216)$ & 0.001 & $(0.001)$ & $-0.012^{*}$ & $(0.006)$ & $-0.031^{*}$ & $(0.017)$ \\
Tax Number & $-1.304^{* * *}$ & $(0.417)$ & 0.001 & $(0.001)$ & $-0.010^{*}$ & $(0.006)$ & $-0.032^{*}$ & $(0.017)$ \\
Tax Time & $-0.007^{* * *}$ & $(0.003)$ & 0.001 & $(0.001)$ & $-0.011^{*}$ & $(0.006)$ & $-0.032^{*}$ & $(0.016)$ \\
Tax Rate & -0.399 & $(0.262)$ & 0.001 & $(0.001)$ & $-0.012^{* *}$ & $(0.006)$ & $-0.033^{*}$ & $(0.017)$ \\
\hline \hline
\end{tabular}

Note: This table reports the results from least squares estimation of the specification (9), where the dependent variable is ICT Investment. All regressions include industry and country dummies. The number of observations is $364, R^{2}$ varies from 0.55 to 0.57 . Robust (clustered) standard errors are in parentheses. $* * *$ indicates significance at the $1 \%$ level, $* *$ at the $5 \%$ level, and * at the $10 \%$ level.

Table 14: Robustness Check - Expected Growth of Value Added Without the Contribution of ICT

\begin{tabular}{lllllllll}
\hline \hline \multicolumn{1}{c}{ Regulation } & \multicolumn{2}{c}{$\begin{array}{c}\text { ICT Dependence } \\
\text { Regulation }\end{array}$} & \multicolumn{2}{c}{$K_{I C T}$} & & & & $\tilde{g}_{V A}$ \\
\hline Entry Procedures & $-3.058^{* * *}$ & $(1.104)$ & 0.001 & $(0.001)$ & $-0.011^{* *}$ & $(0.005)$ & $-0.023^{*}$ & $(0.013)$ \\
Entry Time & $-0.062^{* *}$ & $(0.030)$ & 0.001 & $(0.001)$ & $-0.011^{*}$ & $(0.006)$ & $-0.027^{*}$ & $(0.015)$ \\
Entry Cost & $-1.288^{* * *}$ & $(0.410)$ & 0.001 & $(0.001)$ & $-0.012^{* *}$ & $(0.005)$ & $-0.025^{*}$ & $(0.014)$ \\
Minimum Capital & -0.007 & $(0.101)$ & 0.001 & $(0.001)$ & $-0.010^{*}$ & $(0.006)$ & $-0.029^{*}$ & $(0.015)$ \\
Property Procedures & $-4.549^{*}$ & $(2.620)$ & 0.001 & $(0.001)$ & $-0.011^{*}$ & $(0.006)$ & $-0.029^{* *}$ & $(0.014)$ \\
Property Time & $-0.018^{* * *}$ & $(0.005)$ & 0.001 & $(0.001)$ & $-0.010^{*}$ & $(0.006)$ & $-0.027^{*}$ & $(0.015)$ \\
Property Cost & -2.252 & $(1.558)$ & 0.000 & $(0.001)$ & $-0.011^{*}$ & $(0.006)$ & $-0.028^{*}$ & $(0.015)$ \\
Legal Rights & $0.225^{*}$ & $(0.135)$ & 0.001 & $(0.001)$ & $-0.011^{*}$ & $(0.006)$ & $-0.028^{*}$ & $(0.015)$ \\
Credit Info & -0.075 & $(0.176)$ & 0.001 & $(0.001)$ & $-0.011^{*}$ & $(0.006)$ & $-0.029^{*}$ & $(0.015)$ \\
Business Disclosure & -0.019 & $(0.128)$ & 0.001 & $(0.001)$ & $-0.011^{*}$ & $(0.006)$ & $-0.029^{*}$ & $(0.015)$ \\
Director Liability & 0.091 & $(0.167)$ & 0.001 & $(0.001)$ & $-0.011^{*}$ & $(0.006)$ & $-0.030^{*}$ & $(0.015)$ \\
Ease of Suits & 0.257 & $(0.202)$ & 0.001 & $(0.001)$ & $-0.011^{*}$ & $(0.006)$ & $-0.028^{*}$ & $(0.015)$ \\
Tax Number & $-1.274^{* * *}$ & $(0.395)$ & 0.001 & $(0.001)$ & -0.009 & $(0.006)$ & $-0.026^{*}$ & $(0.015)$ \\
Tax Time & $-0.007^{* * *}$ & $(0.003)$ & 0.001 & $(0.001)$ & $-0.011^{*}$ & $(0.006)$ & $-0.027^{*}$ & $(0.014)$ \\
Tax Rate & -0.373 & $(0.245)$ & 0.001 & $(0.001)$ & $-0.012^{* *}$ & $(0.006)$ & $-0.029^{*}$ & $(0.015)$ \\
\hline \hline
\end{tabular}

Note: This table reports the results from estimation of the specification (9), where the dependent variable is ICT Investment. As a robustness check, we replace expected TFP growth rate with a measure of expected value added growth $\left(\tilde{g}_{V A}\right)$. To construct $\tilde{g}_{V A}$, we subtract the contribution of ICT to value added growth from the growth rate of value added and average this difference over the period 2005-2007. Estimation method is Tobit with [0,1] censoring. All regressions include industry and country dummies. Number of observations is 364, and F-statistics vary from 13.26 to 16.41 . Robust (clustered) standard errors are in parentheses. *** indicates significance at the $1 \%$ level, ** at the $5 \%$ level, and * at the $10 \%$ level. 
Table 15: Robustness Check - Sample Selection: Without the US

\begin{tabular}{llllllllll}
\hline \hline \multicolumn{1}{c}{ Regulation } & \multicolumn{2}{c}{$\begin{array}{c}\text { ICT Dependencex } \\
\text { Regulation }\end{array}$} & \multicolumn{2}{c}{$K_{I C T}$} & & $r$ & & $g_{A}$ \\
\hline Entry Procedures & $-2.943^{* * *}$ & $(1.091)$ & 0.001 & $(0.001)$ & $-0.010^{*}$ & $(0.006)$ & $-0.029^{*}$ & $(0.015)$ \\
Entry Time & $-0.054^{*}$ & $(0.029)$ & 0.001 & $(0.001)$ & -0.010 & $(0.006)$ & $-0.031^{*}$ & $(0.016)$ \\
Entry Cost & $-1.197^{* * *}$ & $(0.423)$ & 0.001 & $(0.001)$ & $-0.011^{*}$ & $(0.006)$ & $-0.031^{* *}$ & $(0.016)$ \\
Minimum Capital & 0.059 & $(0.102)$ & 0.001 & $(0.001)$ & -0.010 & $(0.006)$ & $-0.033^{*}$ & $(0.017)$ \\
Property Procedures & -4.051 & $(2.557)$ & 0.001 & $(0.001)$ & -0.010 & $(0.006)$ & $-0.032^{* *}$ & $(0.016)$ \\
Property Time & $-0.016^{* * *}$ & $(0.005)$ & $0.001^{*}$ & $(0.001)$ & -0.009 & $(0.006)$ & $-0.031^{*}$ & $(0.016)$ \\
Property Cost & -1.400 & $(1.648)$ & 0.001 & $(0.001)$ & -0.010 & $(0.006)$ & $-0.032^{*}$ & $(0.017)$ \\
Legal Rights & 0.171 & $(0.140)$ & 0.001 & $(0.001)$ & -0.010 & $(0.006)$ & $-0.032^{*}$ & $(0.016)$ \\
Credit Info & -0.179 & $(0.170)$ & 0.001 & $(0.001)$ & $-0.010^{*}$ & $(0.006)$ & $-0.032^{*}$ & $(0.016)$ \\
Business Disclosure & -0.053 & $(0.125)$ & 0.001 & $(0.001)$ & -0.010 & $(0.006)$ & $-0.032^{*}$ & $(0.017)$ \\
Director Liability & -0.112 & $(0.163)$ & 0.001 & $(0.001)$ & -0.009 & $(0.006)$ & $-0.031^{*}$ & $(0.016)$ \\
Ease of Suits & 0.106 & $(0.200)$ & 0.001 & $(0.001)$ & -0.010 & $(0.006)$ & $-0.032^{*}$ & $(0.017)$ \\
Tax Number & $-1.152^{* * *}$ & $(0.384)$ & $0.001^{*}$ & $(0.001)$ & -0.008 & $(0.006)$ & $-0.032^{*}$ & $(0.017)$ \\
Tax Time & $-0.008^{* * *}$ & $(0.003)$ & 0.001 & $(0.001)$ & -0.010 & $(0.006)$ & $-0.031^{*}$ & $(0.016)$ \\
Tax Rate & -0.357 & $(0.246)$ & 0.001 & $(0.001)$ & $-0.011^{*}$ & $(0.006)$ & $-0.033^{*}$ & $(0.017)$ \\
\hline \hline
\end{tabular}

Note: This table reports the results from estimation of the specification (9), where the US is excluded from the sample, and the dependent variable is ICT Investment. The estimation method is Tobit with [0,1] censoring. All regressions include industry and country dummies. The number of observations is 338, and F-statistics vary from 12.93 to 15.86 . Robust (clustered) standard errors are in parentheses. $* * *$ indicates significance at the $1 \%$ level, $* *$ at the $5 \%$ level, and $*$ at the $10 \%$ level.

Table 16: Robustness Check - Sample Selection: Without High $K_{I C T}$

\begin{tabular}{|c|c|c|c|c|c|c|c|c|}
\hline \multirow{2}{*}{$\begin{array}{c}\text { Regulation } \\
\text { Entry Procedures }\end{array}$} & \multicolumn{2}{|c|}{$\begin{array}{l}\text { ICT Dependence } \times \\
\text { Regulation }\end{array}$} & \multicolumn{2}{|c|}{$K_{I C T}$} & \multicolumn{2}{|l|}{$r$} & \multicolumn{2}{|c|}{$g_{A}$} \\
\hline & $-2.722^{* * *}$ & $(0.896)$ & 0.001 & $(0.001)$ & $-0.009 * *$ & $(0.004)$ & $-0.028^{*}$ & $(0.015)$ \\
\hline Entry Time & $-0.064 * *$ & $(0.029)$ & 0.001 & $(0.001)$ & $-0.008^{*}$ & $(0.004)$ & $-0.030^{*}$ & $(0.015)$ \\
\hline Entry Cost & $-1.465^{* * *}$ & $(0.368)$ & 0.001 & $(0.001)$ & $-0.010^{* * *}$ & $(0.004)$ & $-0.030 * *$ & $(0.015)$ \\
\hline Minimum Capital & -0.069 & $(0.096)$ & 0.001 & $(0.001)$ & -0.007 & $(0.004)$ & $-0.030^{*}$ & $(0.016)$ \\
\hline Property Procedures & $-3.240^{*}$ & $(1.685)$ & 0.001 & $(0.001)$ & $-0.008^{*}$ & $(0.004)$ & $-0.030^{* *}$ & $(0.015)$ \\
\hline Property Time & $-0.017^{* * *}$ & $(0.005)$ & $0.001^{*}$ & $(0.001)$ & -0.007 & $(0.004)$ & $-0.030^{*}$ & $(0.015)$ \\
\hline Property Cost & $-2.554^{*}$ & $(1.306)$ & 0.001 & $(0.001)$ & $-0.009^{* *}$ & $(0.004)$ & $-0.030^{*}$ & $(0.016)$ \\
\hline Legal Rights & $0.423^{* * *}$ & $(0.131)$ & 0.001 & $(0.001)$ & $-0.008^{* *}$ & $(0.004)$ & $-0.031^{* *}$ & $(0.016)$ \\
\hline Credit Info & 0.136 & $(0.130)$ & 0.001 & $(0.001)$ & -0.007 & $(0.004)$ & $-0.031^{*}$ & $(0.016)$ \\
\hline Business Disclosure & 0.119 & $(0.085)$ & 0.001 & $(0.001)$ & -0.007 & $(0.004)$ & $-0.030^{*}$ & $(0.016)$ \\
\hline Director Liability & 0.221 & $(0.150)$ & 0.001 & $(0.001)$ & $-0.008^{*}$ & $(0.004)$ & $-0.032^{* *}$ & $(0.016)$ \\
\hline Ease of Suits & $0.327^{*}$ & $(0.178)$ & 0.001 & $(0.001)$ & $-0.008^{*}$ & $(0.004)$ & $-0.029^{*}$ & $(0.016)$ \\
\hline Tax Number & $-1.070 * * *$ & $(0.300)$ & 0.001 & $(0.001)$ & -0.006 & $(0.004)$ & $-0.030^{*}$ & $(0.016)$ \\
\hline Tax Time & $-0.006^{* * *}$ & $(0.002)$ & 0.001 & $(0.001)$ & $-0.008^{*}$ & $(0.004)$ & $-0.030 * *$ & $(0.015)$ \\
\hline Tax Rate & $-0.463^{*}$ & $(0.242)$ & 0.001 & $(0.001)$ & $-0.009 * *$ & $(0.004)$ & $-0.032^{*}$ & $(0.016)$ \\
\hline
\end{tabular}

Note: This table reports the results from estimation of the specification (9), where the dependent variable is ICT Investment. As a robustness check, in each country we exclude the industries which have $K_{I C T}$ higher than the 90 th percentile of $K_{I C T}$ in the country. The estimation method is Tobit with $[0,1]$ censoring. All regressions include industry and country dummies. The number of observations is 340, and F-statistics vary from 14.44 to 18.55 . Robust (clustered) standard errors are in parentheses. $* * *$ indicates significance at the $1 \%$ level, $* *$ at the $5 \%$ level, and * at the $10 \%$ level. 
Table 17: Robustness Check - Level of Competition

\begin{tabular}{|c|c|c|c|c|c|c|c|c|c|c|c|c|}
\hline \multirow{2}{*}{$\begin{array}{c}\text { Regulation } \\
\text { Entry Procedures }\end{array}$} & \multicolumn{2}{|c|}{$\begin{array}{l}\text { ICT Dependence } \times \\
\text { Regulation }\end{array}$} & \multicolumn{2}{|c|}{$K_{I C T}$} & \multicolumn{2}{|c|}{$r$} & \multicolumn{2}{|c|}{$g_{A}$} & \multicolumn{2}{|c|}{$P C M$} & \multicolumn{2}{|c|}{$P C M^{2}$} \\
\hline & $-3.159 * * *$ & $(1.085)$ & 0.001 & $(0.001)$ & -0.010 & $(0.008)$ & $-0.030 * *$ & $(0.014)$ & 0.008 & $(0.019)$ & -0.020 & $(0.018)$ \\
\hline Entry Time & $-0.064^{* *}$ & $(0.031)$ & 0.001 & $(0.001)$ & -0.010 & $(0.009)$ & $-0.032^{* *}$ & $(0.015)$ & 0.007 & $(0.021)$ & -0.017 & $(0.021)$ \\
\hline Entry Cost & $-1.341^{* * *}$ & $(0.412)$ & 0.001 & $(0.001)$ & -0.012 & $(0.008)$ & $-0.032^{* *}$ & $(0.015)$ & 0.012 & $(0.019)$ & -0.024 & $(0.017)$ \\
\hline Minimum Capital & -0.017 & $(0.101)$ & 0.001 & $(0.001)$ & -0.010 & $(0.008)$ & $-0.033^{* *}$ & $(0.016)$ & 0.009 & $(0.021)$ & -0.018 & $(0.021)$ \\
\hline Property Procedures & $-4.841^{*}$ & $(2.553)$ & 0.001 & $(0.001)$ & -0.009 & $(0.008)$ & $-0.033^{* *}$ & $(0.015)$ & 0.007 & $(0.019)$ & -0.022 & $(0.020)$ \\
\hline Property Time & $-0.019 * * *$ & $(0.005)$ & $0.001^{*}$ & $(0.001)$ & -0.010 & $(0.009)$ & $-0.033^{* *}$ & $(0.015)$ & 0.010 & $(0.021)$ & -0.021 & $(0.021)$ \\
\hline Property Cost & -2.209 & $(1.560)$ & 0.001 & $(0.001)$ & -0.011 & $(0.008)$ & $-0.032^{* *}$ & $(0.016)$ & 0.006 & $(0.020)$ & -0.015 & $(0.020)$ \\
\hline Legal Rights & $0.256^{*}$ & $(0.136)$ & 0.001 & $(0.001)$ & -0.011 & $(0.008)$ & $-0.033^{* *}$ & $(0.016)$ & 0.014 & $(0.020)$ & -0.024 & $(0.019)$ \\
\hline Credit Info & -0.072 & $(0.174)$ & 0.001 & $(0.001)$ & -0.011 & $(0.009)$ & $-0.033^{* *}$ & $(0.016)$ & 0.008 & $(0.020)$ & -0.017 & $(0.020)$ \\
\hline Business Disclosure & -0.016 & $(0.124)$ & 0.001 & $(0.001)$ & -0.011 & $(0.009)$ & $-0.033^{* *}$ & $(0.016)$ & 0.008 & $(0.020)$ & -0.018 & $(0.020)$ \\
\hline Director Liability & 0.090 & $(0.168)$ & 0.001 & $(0.001)$ & -0.011 & $(0.009)$ & $-0.034 * *$ & $(0.016)$ & 0.009 & $(0.021)$ & -0.018 & $(0.020)$ \\
\hline Ease of Suits & 0.251 & $(0.202)$ & 0.001 & $(0.001)$ & -0.011 & $(0.009)$ & $-0.032^{* *}$ & $(0.016)$ & 0.007 & $(0.021)$ & -0.017 & $(0.021)$ \\
\hline Tax Number & $-1.308^{* * *}$ & $(0.394)$ & 0.001 & $(0.001)$ & -0.010 & $(0.008)$ & $-0.032^{* *}$ & $(0.016)$ & 0.010 & $(0.020)$ & -0.020 & $(0.019)$ \\
\hline Tax Time & $-0.007^{* * *}$ & $(0.003)$ & 0.001 & $(0.001)$ & -0.011 & $(0.008)$ & $-0.032^{* *}$ & $(0.015)$ & 0.008 & $(0.020)$ & -0.015 & $(0.019)$ \\
\hline Tax Rate & -0.399 & $(0.244)$ & 0.001 & $(0.001)$ & -0.012 & $(0.008)$ & $-0.034^{* *}$ & $(0.016)$ & 0.010 & $(0.020)$ & -0.019 & $(0.019)$ \\
\hline
\end{tabular}

Note: This table reports the results from estimation of the specification (9), where the dependent variable is ICT Investment. As a robustness check, we add price-cost margin $P C M$ and its square $P C M^{2}$ to control variables $X_{i, c}$ in $(9)$. We define $P C M$ as the ratio of total capital compensation to nominal output in each industry in countries of our sample. $P C M$ and $P C M^{2}$ do not appear to be jointly significant in these regressions. The reason why this happens could be that the industry and country dummies have already taken into account much of the effects of competition. A simple ANOVA exercise reveals that these dummies explain about 70 percent of variation in $P C M$ and $P C M^{2}$. The estimation method is Tobit with [0,1] censoring. All regressions include industry and country dummies. The number of observations is 364 , and F-statistics vary from 13.06 to 16.22 . Robust (clustered) standard errors are in parentheses. $* * *$ indicates significance at the $1 \%$ level, $* *$ at the $5 \%$ level, and $*$ at the $10 \%$ level.

Table 18: Robustness Check - Competition Level in US Industries and Regulations

\begin{tabular}{|c|c|c|c|c|c|c|c|c|c|c|}
\hline \multirow{2}{*}{$\begin{array}{c}\text { Regulation } \\
\text { Entry Procedures }\end{array}$} & \multicolumn{2}{|c|}{$\begin{array}{l}\text { ICT Dependence } \times \\
\text { Regulation }\end{array}$} & \multicolumn{2}{|c|}{$\begin{array}{l}P C M_{U S} \times \\
\text { Regulation }\end{array}$} & \multicolumn{2}{|c|}{$K_{I C T}$} & \multicolumn{2}{|c|}{$r$} & \multicolumn{2}{|c|}{$g_{A}$} \\
\hline & $-2.909^{* *}$ & $(1.145)$ & 0.200 & $(0.150)$ & 0.001 & $(0.001)$ & $-0.012^{* *}$ & $(0.005)$ & $-0.030 * *$ & $(0.014)$ \\
\hline Entry Time & $-0.061^{*}$ & $(0.032)$ & 0.003 & $(0.004)$ & 0.001 & $(0.001)$ & $-0.011^{*}$ & $(0.006)$ & $-0.032^{* *}$ & $(0.015)$ \\
\hline Entry Cost & $-1.261 * * *$ & $(0.425)$ & 0.060 & $(0.055)$ & 0.001 & $(0.001)$ & $-0.013^{* *}$ & $(0.005)$ & $-0.032 * *$ & $(0.015)$ \\
\hline Minimum Capital & -0.010 & $(0.103)$ & 0.001 & $(0.013)$ & 0.001 & $(0.001)$ & $-0.011 * *$ & $(0.006)$ & $-0.032 * *$ & $(0.016)$ \\
\hline Property Procedures & -4.374 & $(2.736)$ & 0.174 & $(0.363)$ & 0.001 & $(0.001)$ & $-0.012 * *$ & $(0.005)$ & $-0.032 * *$ & $(0.015)$ \\
\hline Property Time & $-0.017 * * *$ & $(0.005)$ & 0.001 & $(0.001)$ & $0.001^{*}$ & $(0.001)$ & $-0.011^{*}$ & $(0.006)$ & $-0.032 * *$ & $(0.015)$ \\
\hline Property Cost & -2.159 & $(1.632)$ & 0.102 & $(0.196)$ & 0.001 & $(0.001)$ & $-0.012^{* *}$ & $(0.006)$ & $-0.032 * *$ & $(0.016)$ \\
\hline Legal Rights & $0.232^{*}$ & $(0.141)$ & -0.008 & $(0.020)$ & 0.001 & $(0.001)$ & $-0.012 * *$ & $(0.006)$ & $-0.033^{* *}$ & $(0.016)$ \\
\hline Credit Info & -0.068 & $(0.183)$ & 0.004 & $(0.023)$ & 0.001 & $(0.001)$ & $-0.012^{* *}$ & $(0.006)$ & $-0.032 * *$ & $(0.016)$ \\
\hline Business Disclosure & -0.021 & $(0.134)$ & -0.007 & $(0.019)$ & 0.001 & $(0.001)$ & $-0.011^{*}$ & $(0.006)$ & $-0.032^{* *}$ & $(0.016)$ \\
\hline Director Liability & 0.100 & $(0.175)$ & 0.006 & $(0.020)$ & 0.001 & $(0.001)$ & $-0.011^{*}$ & $(0.006)$ & $-0.033^{*} *$ & $(0.016)$ \\
\hline Ease of Suits & 0.255 & $(0.212)$ & 0.002 & $(0.023)$ & 0.001 & $(0.001)$ & $-0.012^{* *}$ & $(0.006)$ & $-0.031 * *$ & $(0.016)$ \\
\hline Tax Number & $-1.239 * * *$ & $(0.410)$ & 0.058 & $(0.056)$ & 0.001 & $(0.001)$ & $-0.010^{*}$ & $(0.006)$ & $-0.033^{* *}$ & $(0.016)$ \\
\hline Tax Time & $-0.007 * *$ & $(0.003)$ & $0.001 *$ & $(0.000)$ & 0.001 & $(0.001)$ & $-0.011 * *$ & $(0.006)$ & $-0.033 * *$ & $(0.015)$ \\
\hline Tax Rate & -0.390 & $(0.256)$ & 0.009 & $(0.037)$ & 0.001 & $(0.001)$ & $-0.013^{* *}$ & $(0.006)$ & $-0.033^{* *}$ & $(0.016)$ \\
\hline
\end{tabular}

Note: This table reports the results from estimation of the specification (9), where the dependent variable is ICT Investment. As a robustness check, we add interaction term between competition in US industries and regulations $P C M_{U S} \times$ Regualtion to control variables $X_{i, c}$ in (9). The estimation method is Tobit with [0,1] censoring. All regressions include industry and country dummies. The number of observations is 364 , and F-statistics vary from 12.87 to 16.70 . Robust (clustered) standard errors are in parentheses. $* * *$ indicates significance at the $1 \%$ level, ** at the $5 \%$ level, and * at the $10 \%$ level. 
Table 19: Robustness Check - ICT Specific Interest Rate

\begin{tabular}{|c|c|c|c|c|c|c|c|c|c|c|}
\hline \multirow{2}{*}{$\begin{array}{c}\text { Regulation } \\
\text { Entry Procedures }\end{array}$} & \multicolumn{2}{|c|}{$\begin{array}{l}\text { ICT Dependence } \times \\
\text { Regulation }\end{array}$} & \multicolumn{2}{|c|}{$K_{I C T}$} & \multicolumn{2}{|c|}{$r_{I C T}$} & \multicolumn{2}{|l|}{$r$} & \multicolumn{2}{|c|}{$g_{A}$} \\
\hline & $-2.899 * * *$ & $(1.057)$ & 0.001 & $(0.001)$ & 1.005 & (1.087) & $-0.017^{* *}$ & $(0.007)$ & $-0.033^{* *}$ & $(0.015)$ \\
\hline Entry Time & $-0.062 * *$ & $(0.029)$ & 0.001 & $(0.001)$ & 1.232 & (1.136) & $-0.018^{* *}$ & $(0.007)$ & $-0.036^{* *}$ & $(0.016)$ \\
\hline Entry Cost & $-1.259 * * *$ & $(0.396)$ & 0.001 & $(0.001)$ & 1.095 & (1.097) & $-0.019 * * *$ & $(0.007)$ & $-0.035^{* *}$ & $(0.015)$ \\
\hline Minimum Capital & -0.006 & $(0.099)$ & 0.001 & $(0.001)$ & 1.271 & $(1.136)$ & $-0.018^{* *}$ & $(0.007)$ & $-0.037 * *$ & $(0.016)$ \\
\hline Property Procedures & -3.972 & $(2.569)$ & 0.001 & $(0.001)$ & 1.082 & $(1.118)$ & $-0.017 * *$ & $(0.007)$ & $-0.036 * *$ & $(0.016)$ \\
\hline Property Time & $-0.018^{* * *}$ & $(0.005)$ & $0.001 *$ & $(0.001)$ & 1.202 & $(1.124)$ & $-0.017^{* *}$ & $(0.007)$ & $-0.036^{* *}$ & $(0.016)$ \\
\hline Property Cost & -2.179 & $(1.499)$ & 0.001 & $(0.001)$ & 1.239 & $(1.127)$ & $-0.018^{* *}$ & $(0.007)$ & $-0.036 * *$ & $(0.016)$ \\
\hline Legal Rights & $0.247^{*}$ & $(0.132)$ & 0.001 & $(0.001)$ & 1.295 & $(1.128)$ & $-0.018^{* *}$ & $(0.007)$ & $-0.037^{* *}$ & $(0.016)$ \\
\hline Credit Info & -0.041 & $(0.168)$ & 0.001 & $(0.001)$ & 1.257 & $(1.126)$ & $-0.018^{* *}$ & $(0.007)$ & $-0.037^{* *}$ & $(0.016)$ \\
\hline Business Disclosure & 0.005 & $(0.124)$ & 0.001 & $(0.001)$ & 1.274 & $(1.131)$ & $-0.018^{* *}$ & $(0.007)$ & $-0.037 * *$ & $(0.016)$ \\
\hline Director Liability & 0.103 & $(0.161)$ & 0.001 & $(0.001)$ & 1.285 & $(1.128)$ & $-0.018^{* *}$ & $(0.007)$ & $-0.038^{* *}$ & $(0.016)$ \\
\hline Ease of Suits & 0.245 & $(0.195)$ & 0.001 & $(0.001)$ & 1.255 & $(1.128)$ & $-0.018^{* *}$ & $(0.007)$ & $-0.036^{* *}$ & $(0.017)$ \\
\hline Tax Number & $-1.210 * * *$ & $(0.376)$ & 0.001 & $(0.001)$ & 1.042 & $(1.103)$ & $-0.016^{* *}$ & $(0.007)$ & $-0.036 * *$ & $(0.016)$ \\
\hline Tax Time & $-0.007 * * *$ & $(0.003)$ & 0.001 & $(0.001)$ & 1.213 & $(1.128)$ & $-0.018^{* *}$ & $(0.007)$ & $-0.036 * *$ & $(0.016)$ \\
\hline Tax Rate & $-0.405^{*}$ & $(0.240)$ & 0.001 & $(0.001)$ & 1.284 & $(1.124)$ & $-0.019 * * *$ & $(0.007)$ & $-0.038^{* *}$ & $(0.017)$ \\
\hline
\end{tabular}

Note: This table reports the results from estimation of the specification (9), where the dependent variable is ICT Investment. As a robustness check, we add ICT capital specific interest rate to control variables $X_{i, c}$ in (9). To construct this measure we divide ICT capital compensation to the price of value added and to the real stock of ICT capital. The estimation method is Tobit with $[0,1]$ censoring. All regressions include industry and country dummies. The number of observations is 364 , and F-statistics vary from 13.12 to 15.72 . Robust (clustered) standard errors are in parentheses. *** indicates significance at the $1 \%$ level, ** at the $5 \%$ level, and * at the $10 \%$ level.

Table 20: Robustness Check - The Measurement of ICT Dependence

\begin{tabular}{llllllllll}
\hline \multicolumn{1}{c}{ Regulation } & \multicolumn{2}{c}{$\begin{array}{c}\text { ICT Dependence } \\
\text { Regulation }\end{array}$} & \multicolumn{2}{c}{$K_{I C T}$} & & $r$ & & & $g_{A}$ \\
\hline Entry Procedures & $-6.517^{* *}$ & $(2.857)$ & 0.001 & $(0.001)$ & $-0.012^{* * *}$ & $(0.005)$ & $-0.025^{*}$ & $(0.013)$ \\
Entry Time & -0.035 & $(0.057)$ & 0.001 & $(0.001)$ & $-0.011^{* *}$ & $(0.006)$ & $-0.032^{* *}$ & $(0.015)$ \\
Entry Cost & $-1.908^{* *}$ & $(0.955)$ & 0.001 & $(0.001)$ & $-0.014^{* * *}$ & $(0.005)$ & $-0.030^{* *}$ & $(0.014)$ \\
Minimum Capital & 0.075 & $(0.185)$ & 0.001 & $(0.001)$ & $-0.012^{* *}$ & $(0.006)$ & $-0.033^{* *}$ & $(0.016)$ \\
Property Procedures & -10.552 & $(7.113)$ & $0.001^{*}$ & $(0.001)$ & $-0.012^{* *}$ & $(0.005)$ & $-0.031^{* *}$ & $(0.014)$ \\
Property Time & $-0.025^{* * *}$ & $(0.010)$ & $0.001^{* *}$ & $(0.001)$ & $-0.010^{*}$ & $(0.006)$ & $-0.031^{* *}$ & $(0.015)$ \\
Property Cost & -2.278 & $(3.330)$ & 0.001 & $(0.001)$ & $-0.012^{* *}$ & $(0.006)$ & $-0.031^{* *}$ & $(0.016)$ \\
Legal Rights & 0.229 & $(0.321)$ & 0.001 & $(0.001)$ & $-0.011^{* *}$ & $(0.006)$ & $-0.032^{* *}$ & $(0.016)$ \\
Credit Info & $-0.707^{* *}$ & $(0.348)$ & 0.000 & $(0.001)$ & $-0.014^{* * *}$ & $(0.005)$ & $-0.031^{*}$ & $(0.016)$ \\
Business Disclosure & -0.165 & $(0.326)$ & 0.001 & $(0.001)$ & $-0.012^{* *}$ & $(0.006)$ & $-0.033^{* *}$ & $(0.016)$ \\
Director Liability & 0.135 & $(0.262)$ & 0.001 & $(0.001)$ & $-0.012^{* *}$ & $(0.006)$ & $-0.033^{* *}$ & $(0.016)$ \\
Ease of Suits & -0.019 & $(0.382)$ & 0.001 & $(0.001)$ & $-0.011^{* *}$ & $(0.006)$ & $-0.032^{* *}$ & $(0.016)$ \\
Tax Number & $-2.312^{* * *}$ & $(0.816)$ & $0.001^{*}$ & $(0.001)$ & -0.009 & $(0.006)$ & $-0.031^{*}$ & $(0.016)$ \\
Tax Time & $-0.017^{* *}$ & $(0.007)$ & 0.001 & $(0.001)$ & $-0.012^{* *}$ & $(0.005)$ & $-0.031^{* *}$ & $(0.015)$ \\
Tax Rate & -0.931 & $(0.585)$ & 0.001 & $(0.001)$ & $-0.014^{* *}$ & $(0.006)$ & $-0.034^{* *}$ & $(0.017)$ \\
\hline \hline
\end{tabular}

Note: This table reports the results from estimation of the specification (9), where we eliminate possible noise in our measure of dependence on ICT using fitted values of the share of ICT capital compensation in industry-country pairs in our sample. of dependence on ICT using fitted values of the share of ICT capital compensation in industry-country pairs in our sample.
We construct these fitted values so that they are not country specific. The dependent variable is ICT Investment. The estimation method is IV (two-stage) Tobit with $[0,1]$ censoring. All regressions include industry and country dummies. The number of observations is 364 , and $\chi^{2}$-statistics vary from 510.75 to 773.27 . Robust (clustered) standard errors are in parentheses. $* * *$ indicates significance at the $1 \%$ level, $* *$ at the $5 \%$ level, and ${ }^{*}$ at the $10 \%$ level. 